\title{
Regional Metamorphism in the Condrey Mountain Quadrangle, North-Central Klamath Mountains, California
}

GEOLOGICAL SURVEY PROFESSIONAL PAPER 1086
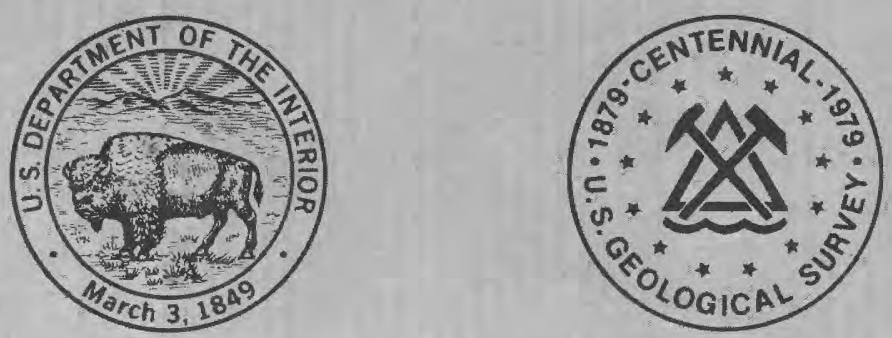


\section{Regional Metamorphism in the Condrey Mountain Quadrangle, North-Central Klamath Mountains, California}

By PRESTON E. HOTZ

GE O L O G I A L S U R V E Y P R O FE S S I O N A L P A P E R I086

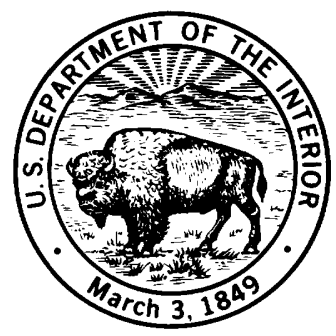

UNITED STATES GOVERNMENT PRINTING OFFICE, WASHINGTON : 1979 
UNITED STATES DEPARTMENT OF THE INTERIOR

CECIL D. ANDRUS, Secretary

\section{GEOLOGICAL SURVEY}

H. William Menard, Director

Library of Congress catalog-card No. 79-600048

For sale by the Superintendent of Documents, U.S. Government Printing Office Washington, D.C. 20402

Stock Number 024-001-03160-4 


\section{CONTENTS}

\begin{tabular}{|c|c|}
\hline & \\
\hline Page & Page \\
\hline------------------1 & Amphibolite facies $\ldots$ \\
\hline 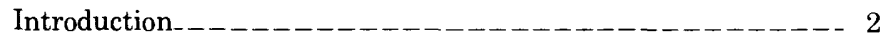 & Foliated amphibolite \\
\hline Greenschist facies & Nonfoliated amphibolite \\
\hline Condrey Mountain Schist $\ldots \ldots \ldots$ & Chemical composition \\
\hline Quartz-muscovite schist & Metasedimentary rocks \\
\hline Chemical composition & Age \\
\hline Actinolite-chlorite schist & Mafic and ultramafic rocks \\
\hline Chemical composition _.______ & Serpentinite \\
\hline Metamorphosed granitic (?) rock _________ 7 & Gabbro and pyroxenite \\
\hline Age and correlation & Age \\
\hline Metavolcanic and metasedimentary rocks of the & Plutonic rocks \\
\hline western Paleozoic and Triassic belt _________ 9 & Pyroxene quartz diorite and granodiorite \\
\hline Metavolcanic rocks_______ & Granitic rocks \\
\hline 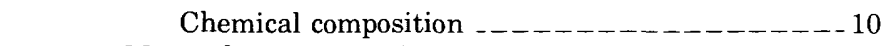 & 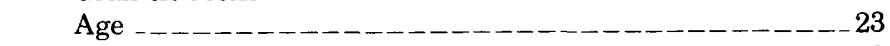 \\
\hline Metasedimentary rocks & Structural and metamorphic relations \\
\hline Age and correlation & References cited \\
\hline
\end{tabular}

\section{ILLUSTRATIONS}

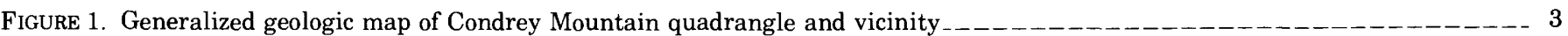

2. Geologic map of Condrey Mountain quadrangle and parts of Seiad Valley and Hornbrook quadrangles _._.

3. Graphs showing $\mathrm{Na}_{2} \mathrm{O}$ and $\mathrm{CaO}$ relative to $\mathrm{SiO}_{2}$ for greenschist from Condrey Mountain Schist____._.

4. AFM diagram of metavolcanic rocks and amphibolite from Condrey Mountain and Hornbrook quadrangles and greenschist from Condrey Mountain Schist

5. Graphs showing $\mathrm{Na}_{2} \mathrm{O}$ and $\mathrm{CaO}$ relative to $\mathrm{SiO}_{2}$ for metavolcanic rocks from Condrey Mountain and

Hornbrook quadrangles _...

6. Photomicrographs of amphibolite, foliated and nonfoliated

7. Diagram of amphiboles in metavolcanic rock and amphibolite from the Condrey Mountain

and Hornbrook quadrangles.

8. Graph showing change in cation content of amphibolite at contact with serpentinite

\section{TABLES}

TABLE 1. Chemical analyses and CIPW norms of quartz-muscovite schist from the Condrey Mountain Schist._-_._- Page

2. Chemical analyses, CIPW norms, and modes of greenschist from the Condrey Mountain Schist

3. Chemical analysis, CIPW norm, and mode of albite-quartz-muscovite-epidote schist _________. 9

4. Chemical and spectrographic analyses and CIPW norms of metavolcanic rock

5. Chemical and spectrographic analyses, CIPW norms, and modes of amphibolite _._.

6. Chemical and spectrographic analysis and CIPW norm of quartz-biotite phyllite

7. Chemical analyses of serpentinite and magnesian schist

8. Chemical analyses illustrating metasomatic reaction at serpentinite-amphibolite contact_______-__-

9. Chemical analyses, CIPW norms, and modes of gabbro, pyroxenite, and pyroxene quartz diorite

10. Chemical and spectrographic analyses, CIPW norms, and modes of rocks from the Vesa Bluffs and Ashland plutons _-_-_-22 



\title{
REGIONAL METAMORPHISM IN THE CONDREY MOUNTAIN QUADRANGLE, NORTH-CENTRAL KLAMATH MOUNTAINS, CALIFORNIA
}

\author{
By Preston E. Hotz
}

\section{ABSTRACT}

A subcircular area of about $650 \mathrm{~km}^{2}$ in northern California and southwestern Oregon is occupied by rocks of the greenschist metamorphic facies called the Condrey Mountain Schist. This greenschist terrane is bordered on the east and west by rocks belonging to the amphibolite metamorphic facies that structurally overlie and are thrust over the Condrey Mountain Schist. The amphibolite facies is succeeded upward by metavolcanic and metasedimentary rocks belonging to the greenschist metamorphic facies.

The Condrey Mountain Schist is composed predominantly of quartz-muscovite schist and lesser amounts of actinolite-chlorite schist formed by the metamorphism of graywacke and spilitic volcanic rocks that may have belonged to the Galice Formation of Late Jurassic age. Potassium-argon age determinations of $141 \pm 4$ m.y. and $155 \pm 5 \mathrm{~m}$.y. obtained on these metamorphic rocks seem to be incompatible with the Late Jurassic age usually assigned the Galice.

The rocks that border the amphibolite facies are part of an extensive terrane of metavolcanic and metasedimentary rocks belonging to the western Paleozoic and Triassic belt. The metavolcanic rocks include some unmetamorphosed spilite but are mostly of the greenschist metamorphic facies composed of oligoclase $\left(\mathrm{An}_{15-20}\right)$ and actinolite with subordinate amounts of chlorite and clinozoisiteepidote. The interbedded sedimentary rocks are predominantly argillite and slaty argillite, less commonly siliceous argillite and chert, and a few lenticular beds of marble. On the south, high-angle faults and a tabular granitic pluton separate the greenschist metavolcanic terrane from the amphibolite facies rocks; on the east, nonfoliated amphibolite is succeeded upward, apparently conformably, by metasedimentary rocks belonging to the greenschist metavolcanic terrane.

In the southern part of Condrey Mountain quadrangle, an outlier of a thrust plate composed of the Stuart Fork Formation overlies the metavolcanic and metasedimentary rocks. The Stuart Fork in this region is composed of siliceous phyllite and phyllitic quartzite and is believed to be the metamorphosed equivalent of rocks over which it is thrust. In the Yreka-Fort Jones area, potassium-argon determinations on mica from the blueschist facies in the Stuart Fork gave ages of approximately $220 \mathrm{~m}$.y. (Late Triassic) for the age of metamorphism.

Rocks of the amphibolite facies structurally overlie the Condrey Mountain Schist along a moderate to steeply dipping thrust fault. The amphibolite terrane is composed of amphibolite and metasedimentary rocks in approximately equal amounts accompanied by many bodies of serpentinite and a number of gabbro and dioritic plutons. Most of the amphibolite is foliated, but some is nonfoliated; the nonfoliated amphibolite has an amphibolite mineralogy and commonly a relict volcanic rock texture. The nonfoliated amphibolite occurs on the southern and eastern borders of the amphibolite terrane between the areas of foliated amphibolite and the overly- ing metavolcanic and metasedimentary rocks. Hornblende and plagioclase $\left(\mathrm{An}_{30-35}\right)$ are the characteristic minerals, indicating that the rocks are of the almandine-amphibolite metamorphic facies. The metasedimentary rocks interbedded with the amphibolites include siliceous schist and phyllite, minor quartzite, and subordinate amounts of marble. Potassium-argon age dates obtained on hornblende from foliated amphibolite yield ages of $146 \pm 4$ and $148 \pm 4$ m.y., suggesting a Late Jurassic metamorphic episode.

Mafic and ultramafic rocks are widespread in the amphibolite terrane but are almost entirely absent from the area of greenschist facies metavolcanic and metasedimentary rocks. The ultramafic rocks, predominantly serpentinite, occur as a few large bodies and many small tabular concordant bodies interleaved with the foliated rocks. The ultramafic rocks include harzburgite and dunite and their serpentinized equivalents. In the Condrey Mountain quadrangle, probably more than 90 percent of the ultramafic rocks is serpentinized. Most of the serpentinite is composed of antigorite formed by metamorphism of serpentinized ultramafic rocks; it is not known whether the metamorphism was of the same episode as that which produced the enclosing amphibolite facies. Some of the serpentinite has been converted to tremolite-, talc-tremolite-, and talc-carbonate rocks. Numerous small bodies of quartz-bearing hornblende gabbro and hornblende pyroxenite are closely associated with some of the serpentinite.

The age of the mafic and ultramafic rocks is uncertain, but they occur as pendants in granitic plutons of Late Jurassic age. The numerous discontinuous bodies of mafic and ultramafic rock scattered throughout the terrane of amphibolite facies rocks suggests a melange, and the association of serpentinite, gabbro, and pyroxenite with amphibolite and siliceous metasedimentary rocks suggests that this assemblage may be part of a dismembered ophiolite suite.

Two large granite plutons, the Ashland and the Vesa Bluffs, range in composition from hornblende gabbro and diorite to quartz diorite; they contain some granodiorite, and alaskitic rock in minor amounts. The Ashland pluton is mainly in Oregon; its southern part is in the northeastern Condrey Mountain and northwestern Hornbrook quadrangles of California. The Vesa Bluffs pluton, a south-dipping tabular body in its western part, occurs between the amphibolite facies on the footwall and a hanging wall of greenschist facies metavolcanic and metasedimentary rocks in the southern Condrey Mountain and southwestern Hornbrook quadrangles. Both plutons enclose roof pendants of serpentinite and pyroxenite or gabbro. Potassium-argon age determinations on hornblende and biotite from these plutons range from $166 \pm 5$ to $144 \pm 4$ m.y.; biotite ages, with one exception, are younger, having a range of $144 \pm 4$ to $147 \pm 4$ m.y.; concordant ages of $146 \pm 4$ and $147 \pm 4 \mathrm{~m}$.y. from hornblende and biotite, respectively, were obtained from only one sample, rock from the Ashland pluton.

The contact between the Condrey Mountain Schist and the overly- 
ing amphibolite and associated metasedimentary rocks is clearly a fault, undoubtedly a thrust modified at many places by high-angle faults. The relation between the higher grade metamorphic rocks and the lower grade metavolcanic and metasedimentary rocks is less well defined. Northwest of the Condrey Mountain quadrangle, metavolcanic rocks overlie metasedimentary rocks belonging to the amphibolite facies, probably along a fault. In the southern Condrey Mountain quadrangle, high-angle faults, serpentinite bodies, and the southward-dipping tabular Vesa Bluffs pluton separate the two terranes. No well-defined contact has been recognized on the east; nonfoliated metavolcanic rocks of the amphibolite facies are succeeded upward conformably by fine-grained metasedimentary rocks that are overlain by metavolcanic rocks of the greenschist facies, apparently with a gradual decrease in intensity of metamorphism stratigraphically upward. A fault that occurs between the foliated and nonfoliated amphibolite may have been the original discontinuity between foliated amphibolite and the metavolcanic and metasedimentary rocks.

During a Triassic tectonic episode, the Stuart Fork Formation, which lies between metavolcanic and metasedimentary rocks of the western Paleozoic and Triassic belt and lower Paleozoic rocks of the eastern Klamath belt, was metamorphosed under lowtemperature-high-pressure conditions of the lawsonite-glaucophane (blueschist) metamorphic facies. Thrusting of the Stuart Fork Formation over the metavolcanic and metasedimentary rocks probably took place during the Triassic and may have continued or have been renewed in the Jurassic.

\section{INTRODUCTION}

Throughout most of the area occupied by the western Paleozoic and Triassic belt in the Klamath Mountains, California and Oregon, the rocks are regionally metamorphosed to the greenschist facies. In the north-central part of the Klamath Mountains, the belt contains rocks belonging to the almandine-amphibolite facies. Other areas of moderate to high-grade metamorphism are known elsewhere in the Klamath Mountains (Kays, 1968, 1970), but this area in the north-central part of the province west and northwest of Yreka is the most extensive (fig. 1). Parts of the area of higher grade metamorphism in California have been mapped in detail by Barrows (1969), Hotz (1967), and Medaris (1966) and in reconnaissance by Pratt (1964); in Oregon, the area is included in reconnaissance maps of the Grants Pass and Medford 30-minute quadrangles (Wells, and others 1940; Wells, 1956) and larger scale studies of small areas by Engelhardt (1966) and Heinrich (1966).

A circular area of approximately $650 \mathrm{~km}^{2}$ on the California-Oregon border, north of the Klamath River, is occupied by highly foliated low-grade schist. The schist is of two main types, quartz-muscovite schist, commonly graphitic, and actinolite-chlorite schist, herein named the Condrey Mountain Schist. Rocks of amphibolite metamorphic facies are in thrust-fault contact with the Condrey Mountain Schist on the east, west, and south (figs. 1, 2). The area occupied by the higher grade metamorphic rocks contains many large and small bodies of ultramafic rock. The amphibolite facies rocks are succeeded outward, and apparently upward in most places, by weakly metamorphosed volcanic and sedimentary rocks. At some places, the change is abrupt as a result of faulting; at other places, the transition is gradual. In the area of lower grade rocks, ultramafic rocks are absent. The weakly metamorphosed volcanic and sedimentary rocks are part of the western Paleozoic and Triassic belt, a broad continuous north-south-trending belt that constitutes the most extensive lithologic subdivision in the Klamath Mountains province.

\section{GREENSCHIST FACIES}

Rocks of the greenschist facies include the Condrey Mountain Schist, metavolcanic and metasedimentary rocks of the western Paleozoic and Triassic belt, and the Stuart Fork Formation.

\section{CONDREY MOUNTAIN SCHIST}

The rocks that occupy the subcircular area mainly north of the Klamath River are here named the Condrey Mountain Schist for a peak of that name (sec. 11, T. 47 N., R. 10 W) in northwestern Condrey Mountain quadrangle. The type locality is designated the exposures on the south side of the Klamath River between Dona and McKinney Creeks (secs. 8 and 9, T. 46 N., R. 9 W.) (fig. 2). The principal reference locality is designated the exposures along a ridge from Condrey Mountain to the saddle between West Fork of Beaver Creek and Wards Fork (NE $1 / 4$ sec. 29, T. 48 N., R. 9 W.). Exposures in the valley of Elliot Creek (T. 48 N., R. 10 and $11 \mathrm{~W}$.), northwest Condrey Mountain, and northern Seiad Valley quadrangles, are considered a supplementary reference locality. This schist is largely constituted of quartz-muscovite schist, commonly graphitic, and actinolite-chlorite schist. Of the two, quartzmuscovite schist is more abundant; greenschist occurs mainly on the borders of the schist outcrop area adjacent to the contact with amphibolite facies rocks.

The following mineral assemblages have been observed: quarts-muscovite-(albite-chlorite-graphite); quartz-albite-muscovite-epidote-(chlorite); quartzalbite-actinolite-chlorite-epidote; albite-actinolitechlorite- epidote-(quartz-muscovite). All are stable mineral assemblages of the quartz-albite-muscovitechlorite (chlorite zone) subfacies (Turner, in Fyfe, and others, 1958, p. 218) of the greenschist facies. An unusual rock with the mineral assemblage glaucophane- 


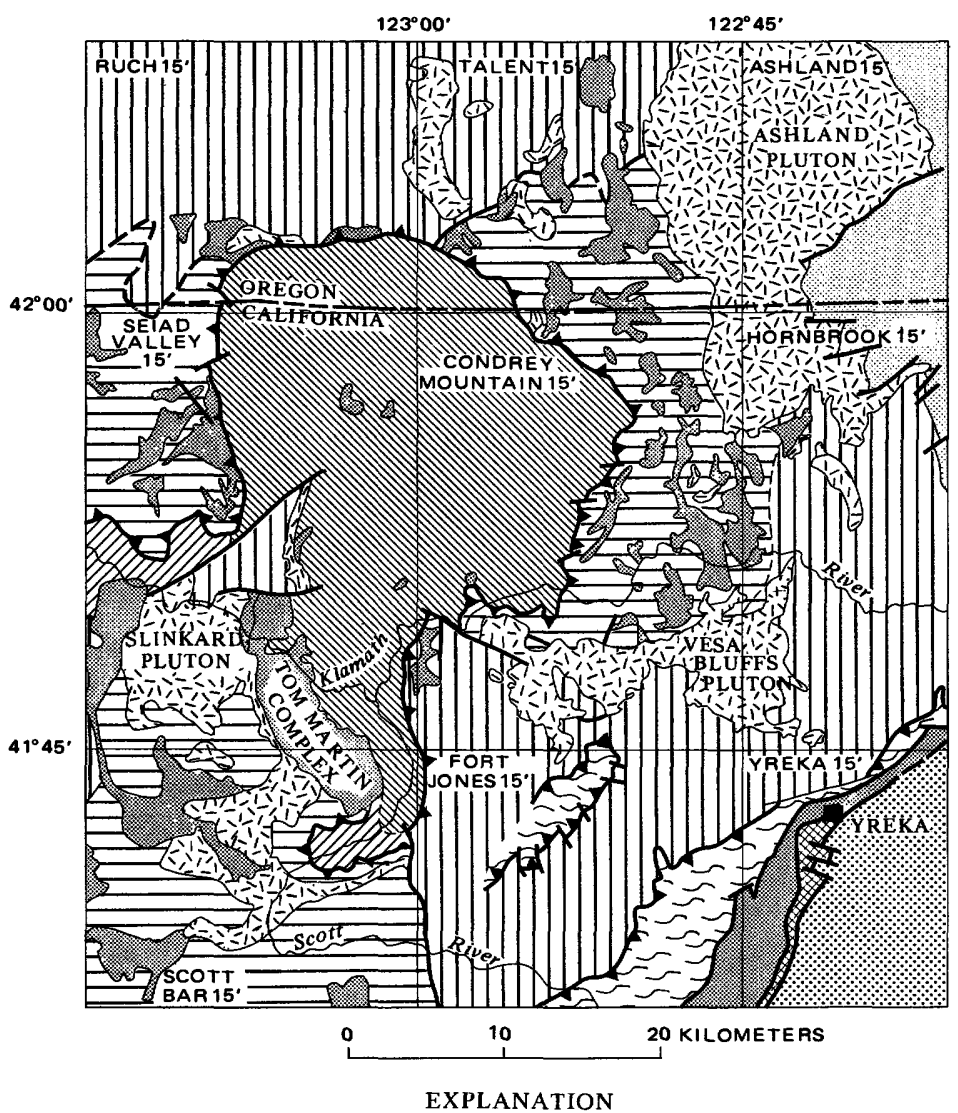

SEDIMENTARY AND METAMORPHIC ROCKS
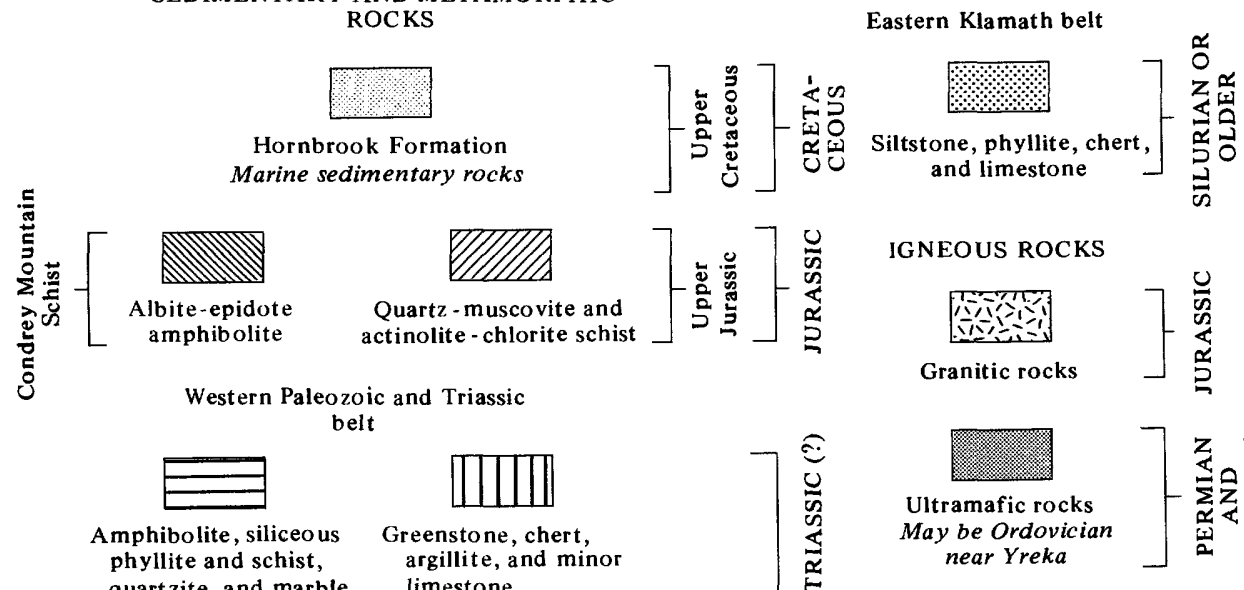

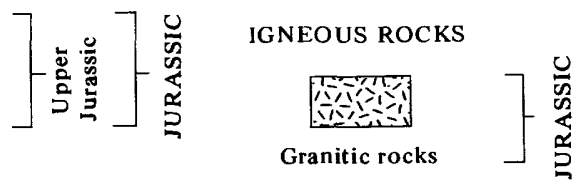

quart zite, and marble limestone

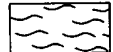

Stuart Fork Formation Phyllitic quartzite, siliceous phyllite, metabasalt, minor limestone, and locally, blueschist

Central metamorphic belt

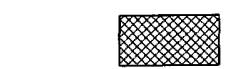

Amphibolite, impure marble, calcareous and siliceous schist

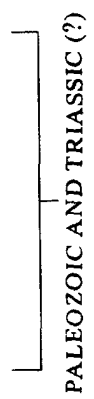

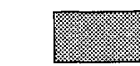

Ultramafic rocks May be Ordovician near Yreka

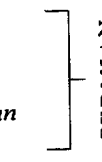

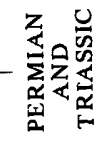

Contact

Dashed where inferred

Fault

Dashed where inferred

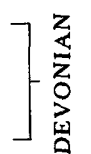

Thrust fault Sawteeth on upper plate

FIGURE 1.-Generalized geologic map of Condrey Mountain quadrangle and vicinity. 


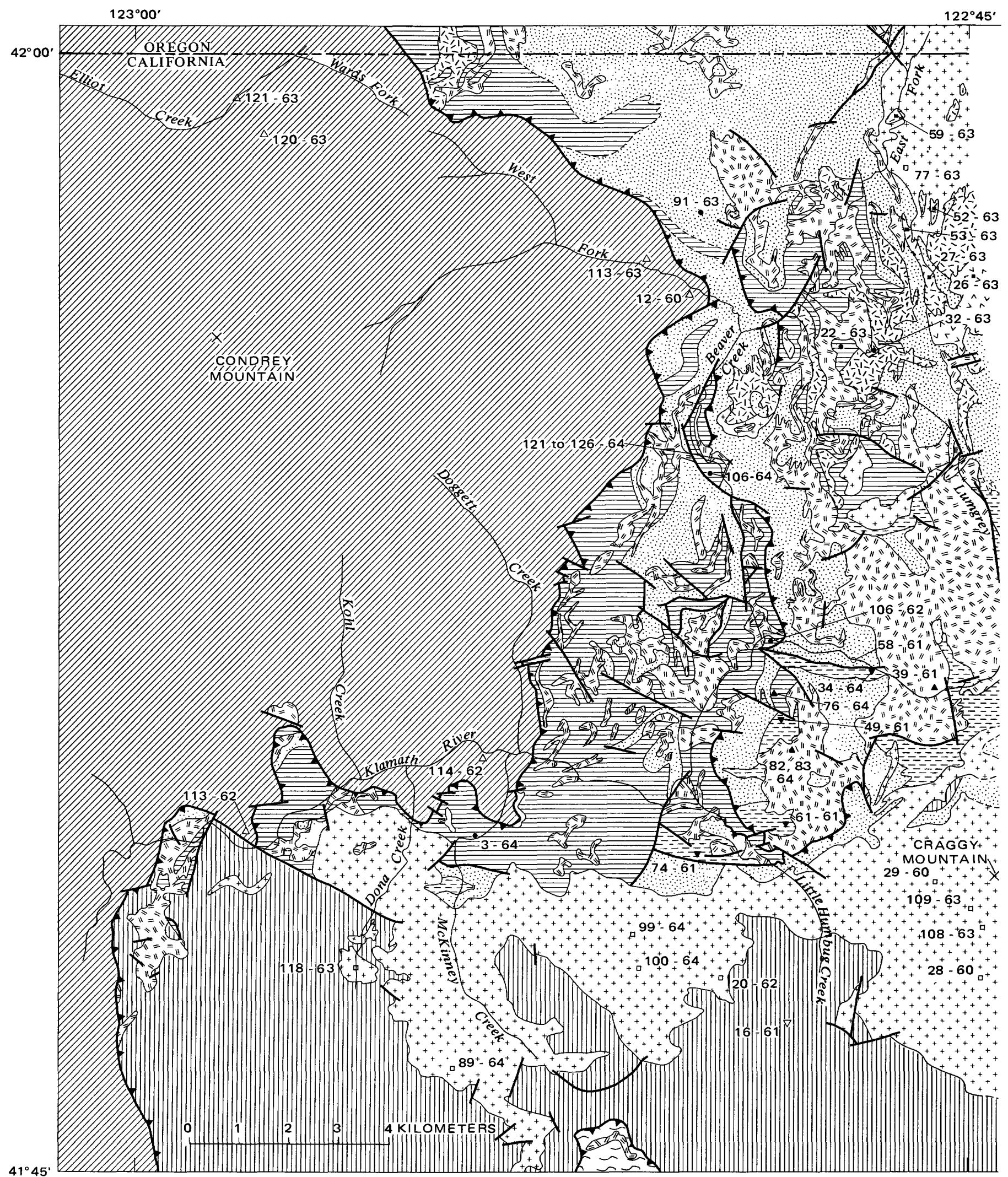

Figure 2.-Geologic map of Condrey Mountain quadrangle 


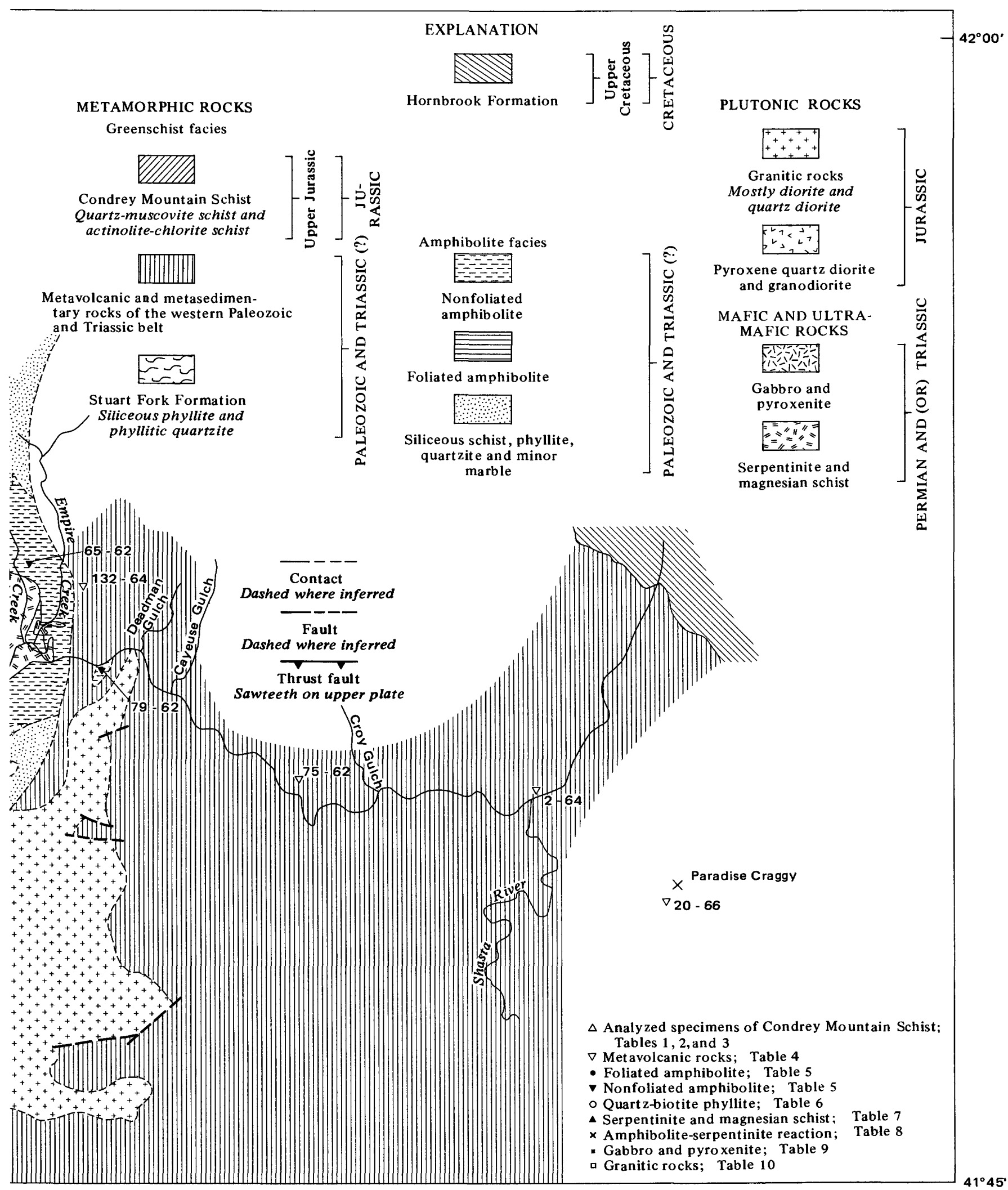

and parts of Seiad Valley and Hornbrook quadrangles. 
epidote-quartz-albite-(chlorite-sphene), found locally, contains no lawsonite and hence also belongs to the greenschist facies despite the glaucophane content.

\section{QUARTZ-MUSCOVITE SCHISI}

Quartz-muscovite schist is the most common variety of the Condrey Mountain Schist. The common mineral assemblage is quartz-muscovite-(albite-chloritegraphite). This schist is a gray to brownish-gray, in some places bluish-gray, fine-grained rock with a well-developed schistosity along which the rock readily splits, revealing shiny cleavage surfaces coated with muscovite. Thin lenticular white microcrystalline siliceous laminae alternate with dark micaceous laminae. Brown iron-oxide pseudomorphs of pyrite as much as $5 \mathrm{~mm}$ in diameter are fairly common. The rocks are very uniform in appearance, grain size, and composition over wide areas. They have no obvious compositional layering except for podlike lenticular bodies of white quartz less than $2.5 \mathrm{~cm}$ to 5 to $7.5 \mathrm{~cm}$ thick and several centimeters long that occur irregularly parallel to the schistosity.

Quartz, the dominant mineral of the schist, occurs as lenticular laminae of elongate anhedral interlocking grains that show obvious strain shadows in crosspolarized light under the microscope.

Albite is generally sparse or absent; where present, it has a habit similar to the quartz except in finegrained mica-rich laminae in some specimens where it occurs as subhedral porphyroblasts with major diameters of 0.7 to more than $2.5 \mathrm{~mm}$. In one specimen, the albite porphyroblasts contained parallel trains of carbonaceous dust in their central parts; rims are of clear albite in the pressure shadows of the metacrysts. The dust trains occur at an angle to the rock foliation, which has a slight tendency to wrap around the crystals; this tendency indicates that there was further movement in the direction of the schistosity after crystallization of the porphyroblasts.

Muscovite, the most abundant micaceous mineral, occurs in alternating laminae with the quartz and as thin folia between some of the quartz grains. Commonly a few flakes and irregular masses of chlorite accompany the muscovite. Chlorite may have a porphyroblastic habit in some specimens where it is oriented with its cleavages at a slight to moderate angle to the schistosity, along which slight movement has caused crinkling and development of an incipient secondary cleavage of the porphyroblasts.

The dark color of this schist, whose major mineral components are light colored, is imparted by a pervasive black dust, apparently carbon concentrated in the micaceous folia.
Many specimens of quartz-muscovite schist contain no other accessory minerals, but some contain a few prismatic grains of actinolite and granules of clinozoisite. Sphene, apatite, and brown tourmaline may be minor accessories in some.

\section{CHEMICAL COMPOSITION}

The quartz-muscovite schist is undoubtedly a metasedimentary rock. Although recrystallization has destroyed all vestiges of original structures and textures and no relict textures can be seen microscopically, the mineralogy, especially the occurrence of graphite, is compatible with derivation from a sedimentary rock, perhaps a fine-grained sandstone. Chemical analyses of two samples of quartz-muscovite schist are given in table 1.

\section{ACTINOLITE-CHLORITE SCHIST}

Actinolite-chlorite schist-believed to be the metamorphosed equivalent of basaltic tuffs and flows,

TABLE 1.-Chemical analyses and CIPW norms of quartz-muscovite schist from the Condrey Mountain Schist

[Chemical analyses by rapid methods; analysts: P. L. D. Elmore, S. D. Botts, Gillison Chloe, Lowell Artis, and Hezekiah Smith. Sample localities shown in fig. 2]

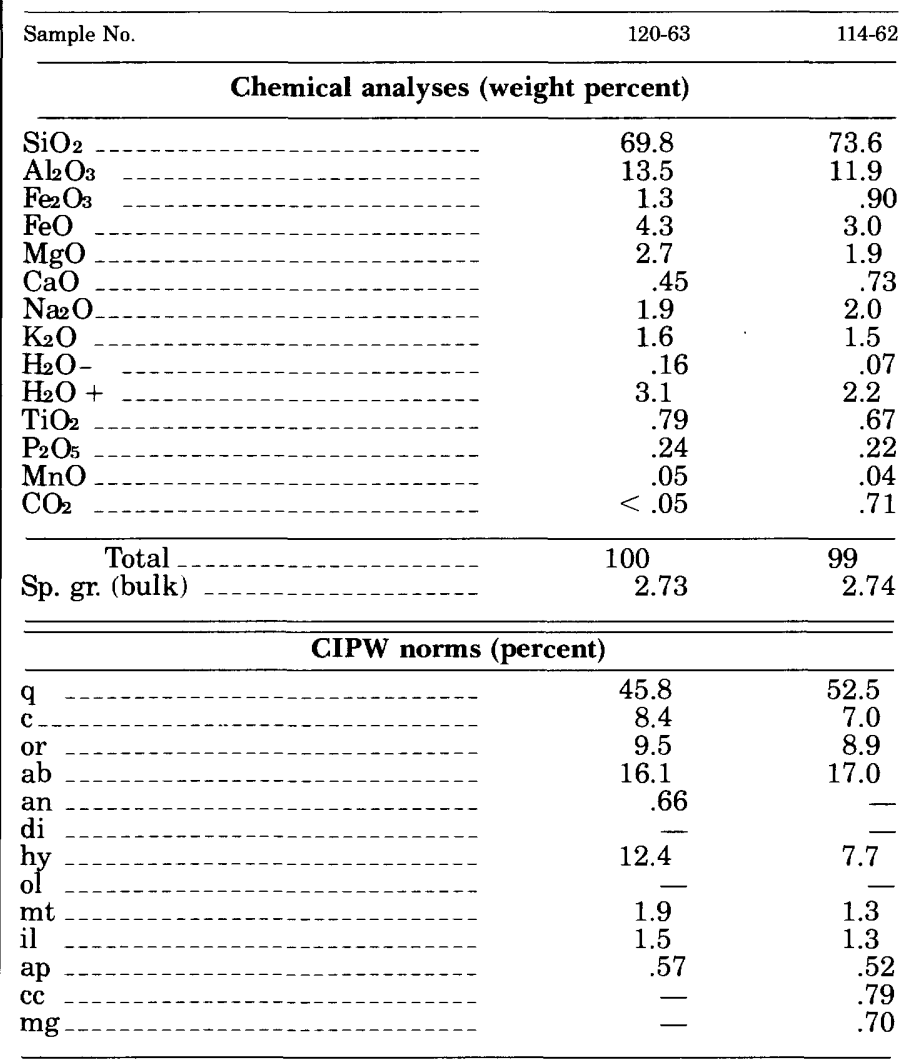

NOTE_-120-63 Quartz-(albite)-muscovite-chlorite schist. East of Dog Fork, NE 1/4 NE1/4 Sec. 25, T. 48 N., R.10 W.

114-62 Quartz-muscovite schist, Center sec. 9, T.46 N., R.9 W. 
constitutes a distinctive variety of the Condrey Mountain Schist. It occurs in a wide continuous belt between quartz-muscovite schist and the amphibolite facies metamorphic rocks in the northern part of Condrey Mountain quadrangle (Hotz, 1967) and as narrow discontinuous bodies elsewhere, both along the boundary with the higher grade rocks and interbedded with the quartz-muscovite schist. It is fine grained, greenish gray to grayish green, and varies from very uniform to finely laminated with thin flattened lenticular laminae alternately rich in ferromagnesian minerals and albite. Textures are crystalloblastic schistose; the average grain size ranges from $0.05 \mathrm{~mm}$ to $1.0 \mathrm{~mm}$. Original textures and structures have been mostly obliterated by recrystallization. Some have a faint compositional layering that suggests laminae of sedimentary origin, and a few contain ovoid twinned albite phenocrysts that may be pseudomorphs of plagioclase and clots of chlorite and actinolite that possibly represent original phenocrysts of mafic minerals.

The mineral assemblages quartz-albite-actinolitechlorite-epidote and albite-actinolite-chloriteepidote-(muscovite) are common. A fine-grained rock with a bluish tinge seen in one place has the assemblage glaucophane-epidote-quartz-albite-(chlorite), but this assemblage is unusual. Sphene is a ubiquitous minor accessory, occurring as tiny, droplike granules, typically enclosed in chlorite and the amphibole. Apatite is present in trace amounts. The quartz content is variable but generally small; quartz is absent from some samples. Quartz occurs with albite, commonly as blebs within the feldspar, but it is also intergrown with it in grains of similar habit; it may also occur in small segregated lenses. Some flakes of muscovite have been observed in nearly all specimens.

\section{CHEMICAL COMPOSITION}

Chemical analyses of three samples of greenschist, given in table 2 , show them to be basaltic in composition. Owing to their relatively high $\mathrm{Na}_{2} \mathrm{O}$ and low $\mathrm{CaO}$ content, they plot in the spilite field on $\mathrm{SiO}_{2}$ $\mathrm{Na}_{2} \mathrm{O}$ and $\mathrm{SiO}_{2}-\mathrm{CaO}$ diagrams (fig. 3) Hamilton, 1963). On an AFM plot (fig. 4), they are similar to the metavolcanic rocks and amphibolites in the area that surrounds the window of schist but they have a slightly lower iron and higher magnesia content than most of the samples.

\section{METAMORPHOSED GRANITIC (?) ROCK}

A small indefinite body of albite-quartz-muscoviteepidote schist (not shown in fig. 2) occurs in the West Fork of Beaver Creek along the contact between greenschist and amphibolite. Megascopically, it is a
TABLE 2.-Chemical analyses, CIPW norms, and modes of greenschist from the Condrey Mountain Schist

[Chemical analyses by rapid methods, analysts: P. L. D. Elmore, S. D. Botts, Gillison Chloe, Lowell Artis, and Hezekia Smith. Sample localities shown in fig. 2]

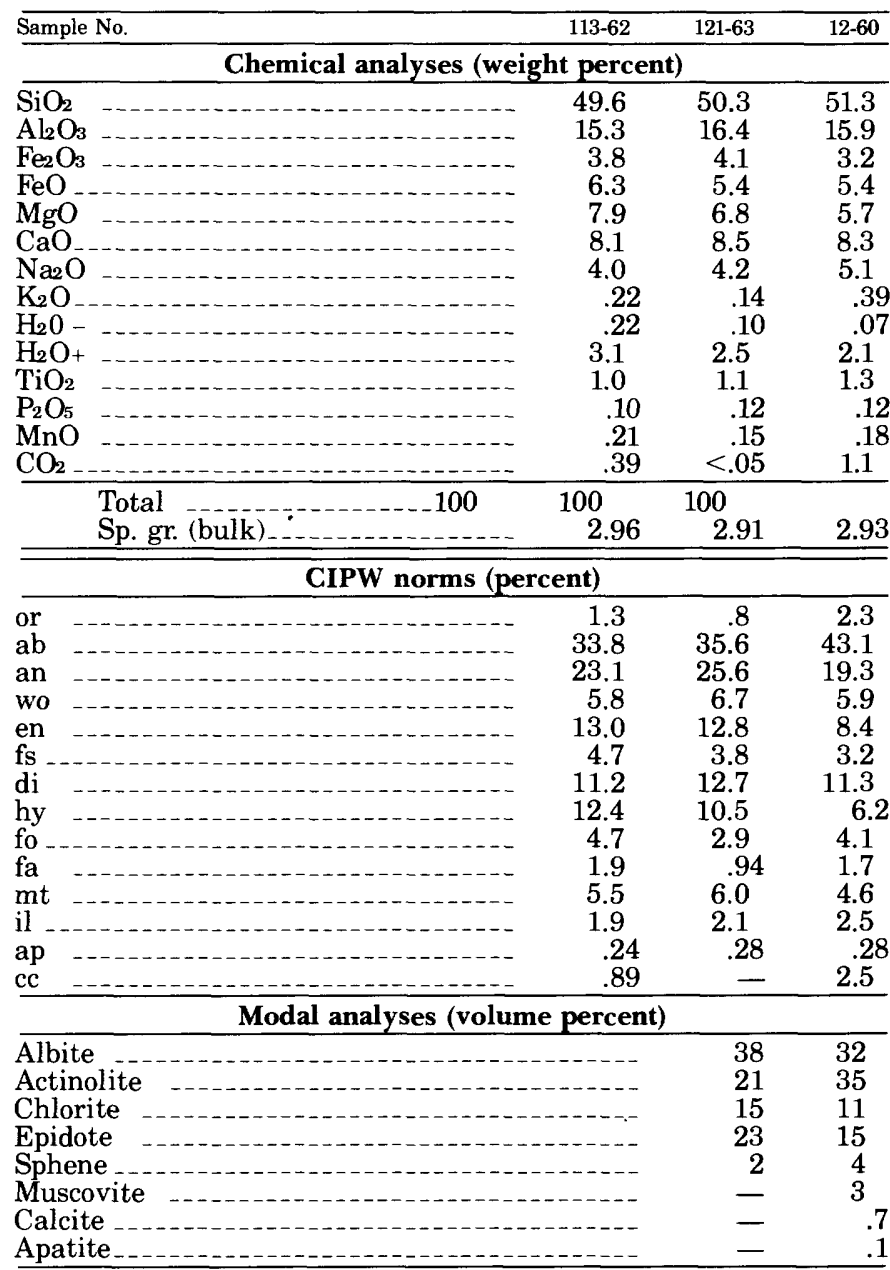

NOTE-113-62 Greenschist, $\mathrm{SE}^{1 / 4}$ sec. 14, T.46 N., R.10 W.

121-63 Greenschist, Elliot Creek, east edge SE1/4, sec. 23, T.48 N., R.10 W 12-60 Greenschist, West Fork Beaver Creek, eastern part, sec. 1, T.47 N., R.9 W.

light-colored, medium-grained schistose rock with visible quartz, feldspar, and white mica. It has large irregular to augen-shaped feldspars and looks like a metamorphosed granitic rock.

Under the microscope, the rock is seen to be composed of anhedral, clear, untwinned albite and quartz. The albite is vaguely rectangular and has a slight preferred orientation; the quartz is in anhedral interstitial bodies, inclusions, and veinlets. Muscovite occurs in roughly parallel flakes and folia that give the rock its faint foliation. Minor quantities of chlorite, epidote, and sphene are present.

A chemical analysis of this rock, presented in table 3, is somewhat puzzling, for it is unlike that of most granitic rocks. $\mathrm{SiO}_{2}$ is very high; $\mathrm{Al}_{2} \mathrm{O}_{3}$ is relatively low, $\mathrm{MgO}$ is somewhat high. Alkali content is rather low for 

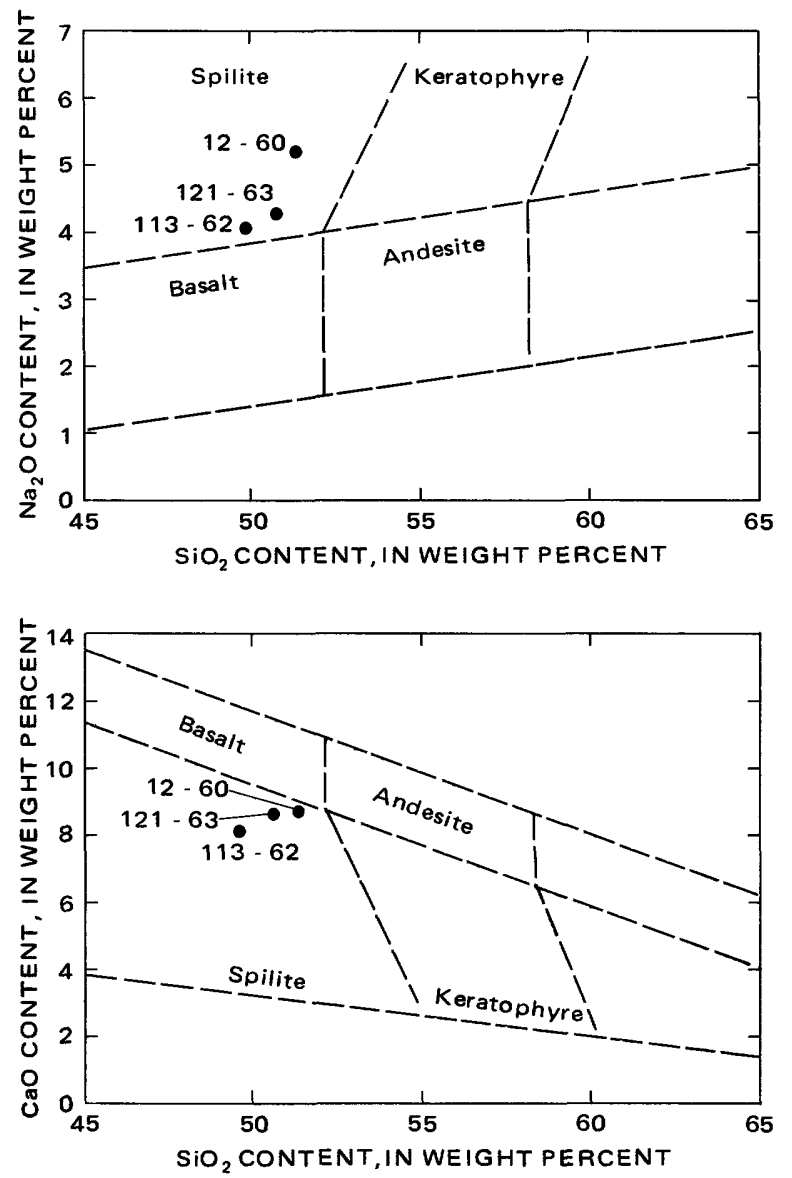

Figure 3.- $-\mathrm{Na}_{2} \mathrm{O}$ and $\mathrm{CaO}$ relative to $\mathrm{SiO}_{2}$ for greenschist from Condrey Mountain Schist (from data given in table 2). Classification from Hamilton (1963, p. 71).

a plutonic rock of this $\mathrm{SiO}_{2}$ content, and $\mathrm{Na}_{2} \mathrm{O}$ is more than twice as abundant as $\mathrm{K}_{2} \mathrm{O}$. The rock may be trondhjemitic, although normative quartz and orthoclase seem too high.

Perhaps this unusual rock is an intrusive of the same general age as the other granitic rocks in the area $\approx 140$ m.y.) and locally has been metamorphosed contemporaneously with the Condrey Mountain Schist.

\section{AGE AND CORRELATION}

Potassium-argon age determinations on muscovite and whole-rock analyses gave dates of 141 m.y. (Lanphere and others, 1968) and $155 \pm 3$ m.y. (Suppe and Armstrong, 1972), respectively, for the Condrey Mountain Schist. The age of metamorphism is therefore Late Jurassic, but the age and correlation of its protolith among known lithologic units of the region is somewhat speculative.

The overall lithology and composition of the Condrey Mountain Schist are indicative of the formation of these metamorphic rocks from sedimentary rocks and

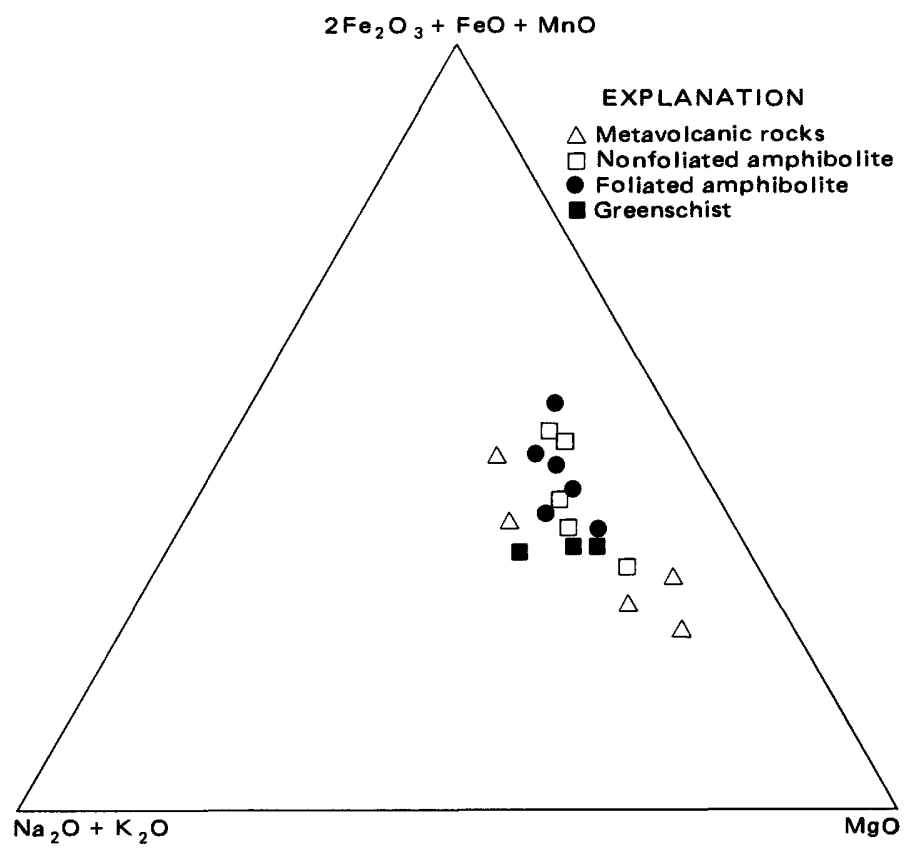

FIGURE 4.-AFM diagram of metavolcanic rocks and amphibolite from Condrey Mountain and Hornbrook quadrangles and greenschist from Condrey Mountain Schist.

subordinate amounts of spilitic volcanic rocks. The Stuart Fork Formation (Davis and Lipman, 1962) has been regarded as a possible correlative (Medaris, 1966), and the style of deformation in these two terranes is similar, but the metasedimentary rocks of the Stuart Fork are predominantly metachert. Furthermore, elsewhere the Stuart Fork is thrust over rocks of the western Paleozoic and Triassic belt, whereas here the schist underlies amphibolite that is beneath rocks of that belt. Suitable parental rocks might be found among some of the Mississippian, Triassic, and Jurassic rocks of the eastern Klamath belt, but the structural problems inherent in explaining their relative positions seem almost unresolvable.

Suppe and Armstrong (1972) thought that the Condrey Mountain Schist of this report resembled the South Fork Mountain Schist, and they concluded therefore that this schist was metamorphosed Franciscan rocks, noting, however, that the date of $155 \mathrm{~m}$.y. they obtained is slightly older than any available Franciscan dates. If these are metamorphosed Franciscan rocks, a structural difficulty exists, for in the Klamath Mountains the Galice Formation lies structurally above Franciscan rocks and the South Fork Mountain Schist and structurally below the western Paleozoic and Triassic belt. It would be difficult to account for the occurrence of a window of Franciscan with no intervening Galice.

The Galice Formation is of suitable lithology and is structurally below the western Paleozoic and Triassic 
TABLE 3.-Chemical analysis, CIPW norm, and mode of albite-quartz-muscovite-epidote schist

[Chemical analyses by rapid methods; analysts: P. L. D. Elmore, S. D. Botts, Gillison Chloe, Lowell Artis, and Hezekiah Smith. Sample locality shown in fig. 2]

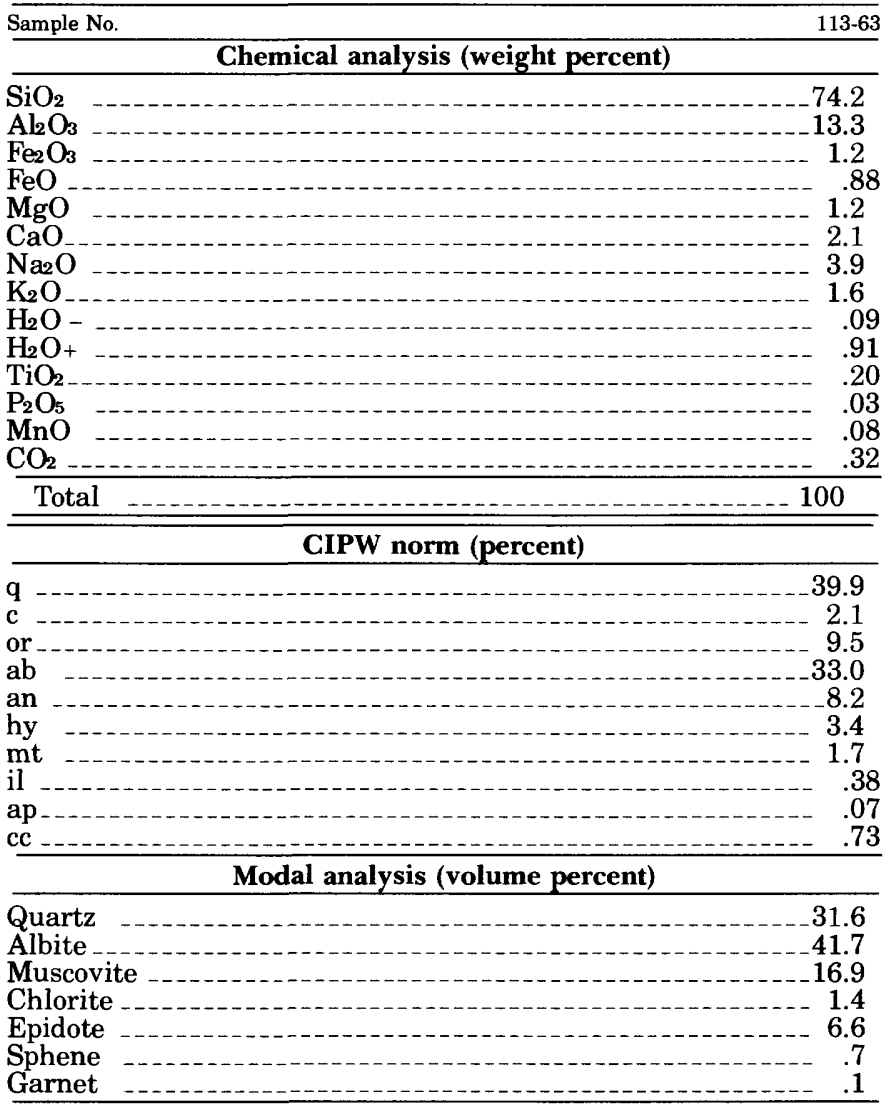

NOTE-113-63 West Fork Beaver Creek, line between secs. 1 and 2, T.49 N., R. 9 W.

belt elsewhere. The area of Condrey Mountain Schist is only about $25 \mathrm{~km}$ east of a reentrant of the Galice at Happy Camp, where Klein (1976) found sedimentary and volcanic rocks of the Galice grading upward into a greenschist facies overridden by amphibolite-grade rock along a thrust fault. The Galice seems to be a suitable protolith structurally as well as lithologically, although its apparent youthfulness (Oxfordian and Kimmeridgian) is incompatible with the metamorphic age of Condrey Mountain Schist. As fossils are not abundant in the Galice and its stratigraphy is poorly known, there may conceivably be parts of the formation older than the metamorphic episode.

\section{METAVOLCANIC AND METASEDIMENTARY ROCKS OF THE WESTERN PALEOZOIC AND TRIASSIC BELT}

Metavolcanic and metasedimentary rocks are almost continuously exposed along the Klamath River from the overlap by rocks of the Cretaceous Hornbrook Formation $6 \mathrm{~km}$ northeast of the mouth of the Shasta River (fig. 2) to the confluence of Empire Creek with the Klamath River, a distance of about $18 \mathrm{~km}$. South of the Vesa Bluffs pluton, metavolcanic and metasedimentary rocks occur as metavolcanic rocks with interbedded chert, slate and phyllite with subordinate amounts of volcanic rock, and interbedded chert and argillite with minor greenstone (Hotz, 1967). Along the Klamath River, metavolcanic rocks crop out from the overlap of Cretaceous sedimentary rocks westward to Croy Gulch, $4 \mathrm{~km}$ west of the mouth of Shasta River (fig. 2). Between Croy Gulch and Deadman Gulch, $7 \mathrm{~km}$ to the west, rocks that crop out are mostly metasedimentary. From Deadman Gulch to the body of ultramafic rocks, rocks exposed are predominantly metavolcanic.

\section{METAVOLCANIC ROCKS}

The metavolcanic rocks are characteristically gray to greenish gray and fine grained to microcrystalline, but locally porphyritic. They are mostly massive and virtually structureless; in some places planar structures are made apparent by variations in composition or grain size. Some are clearly volcanic breccias; pillow structures are recognizable in some exposures but are not common.

The least metamorphosed metavolcanic rocks of the Klamath River section are to the east; they are represented by specimens of spilite from road cuts on the north side of Klamath River at the junction with Shasta River (table 4, sample no. 2-64) and fragmental basalt from exposures on Paradise Craggy about $4 \mathrm{~km}$ southeast of the junction (table 4, sample no. 20-66). These rocks are characterized by the coexistence of unaltered clinopyroxene, albite, and chlorite. There is no alteration of the pyroxene to amphibole, but minor amounts of chlorite occur interstitial to the groundmass albite and pyroxene. Veinlets of carbonate are commonly accompanied by prehnite, and the rock may contain a few small amygdules of calcite rimmed by pale-green chlorite.

Except for these occurrences of unmetamorphosed spilite, the metavolcanic rocks in nearby Shasta Canyon and westward through the Klamath River canyon to the contact with the ultramafic rocks are composed mainly of sodic plagioclase, actinolitic amphibole, minor amounts of chlorite, biotite, and clinozoisiteepidote, accessory sphene, and variable amounts of calcite; typically, opaque accessories are present in very small amounts or absent. To a large extent, the original textures and structures are preserved.

The plagioclase most commonly ranges from oligoclase $\left(\mathrm{An}_{15-20}\right)$ to oligoclase-andesine $\left(\mathrm{An}_{30}\right)$; an exceptional few specimens have feldspar as sodic as albite. Plagioclase commonly occurs as clear subhedral to 
TABLE 4.-Chemical and spectrograpic analyses and CIPW norms of metavolcanic rocks

[Chemical analyses by rapid methods; analysts: P. L. D. Elmore, S. D. Botts, Gillison Chloe, Lowell Artis, James Kelsey, and Hezekiah Smith. Semiquantitative spectrographic analyses by W. B. Crandell, Chris Heropoulos and Carolyn Pickett. Sample localities shown in fig. 2]

\begin{tabular}{|c|c|c|c|c|c|}
\hline Sample No. & $75-62$ & $20-66$ & 16-61 & $2-64$ & $132-64$ \\
\hline \multicolumn{6}{|c|}{ Chemical analyses (weight percent) } \\
\hline $\begin{array}{l}\mathrm{SiO}_{2} \\
\mathrm{Al}_{2} \mathrm{O}_{3} \\
\mathrm{Fe}_{2} \mathrm{O}_{3} \\
\mathrm{FeO} \\
\mathrm{MgO} \mathrm{CgO} \\
\mathrm{CaO}_{2} \\
\mathrm{Ne}_{2} \mathrm{O} \\
\mathrm{K}_{2} \mathrm{O}_{2} \\
\mathrm{H}_{2} \mathrm{O}_{-}- \\
\mathrm{H}_{2} \mathrm{O}+ \\
\mathrm{TiO}_{2} \\
\mathrm{P}_{2} \mathrm{O}_{5} \\
\mathrm{MnO} \mathrm{O} \\
\mathrm{CO}_{2}\end{array}$ & $\begin{array}{c}45.3 \\
14.2 \\
.7 \\
10.3 \\
4.3 \\
8.3 \\
4.2 \\
.55 \\
.07 \\
3.5 \\
2.4 \\
.49 \\
.19 \\
6.0\end{array}$ & $\begin{aligned} 45.7 \\
13.0 \\
5.0 \\
6.4 \\
12.2 \\
7.2 \\
2.3 \\
1.1 \\
.5 \\
3.8 \\
2.2 \\
.35 \\
.18 \\
.08\end{aligned}$ & $\begin{array}{l}48.1 \\
15.0 \\
1.2 \\
9.0 \\
5.7 \\
9.3 \\
4.9 \\
1.4 \\
.08 \\
1.5 \\
2.6 \\
.39 \\
.14 \\
.85\end{array}$ & $\begin{array}{c}50.6 \\
15.0 \\
.66 \\
7.4 \\
9.5 \\
7.4 \\
3.8 \\
.91 \\
.20 \\
3.4 \\
.87 \\
.11 \\
.15 \\
.14\end{array}$ & $\begin{array}{c}53.5 \\
13.7 \\
.55 \\
6.5 \\
10.9 \\
9.5 \\
3.1 \\
.16 \\
.07 \\
1.1 \\
.23 \\
.04 \\
.13 \\
.06\end{array}$ \\
\hline $\begin{array}{c}\text { Total } \\
\text { Sp. gr. (bulk) }\end{array}$ & $\begin{array}{l}100 \\
2.82\end{array}$ & $\begin{array}{l}99 \\
2.99\end{array}$ & $\begin{array}{l}100 \\
2.99\end{array}$ & $\begin{array}{l}100 \\
2.95\end{array}$ & $\begin{array}{l}99 \\
2.71\end{array}$ \\
\hline
\end{tabular}

\begin{tabular}{|c|c|c|c|c|c|}
\hline \multicolumn{6}{|c|}{ Semiquantitative spectrographic analyses (ppm) } \\
\hline $\begin{array}{l}\mathrm{Ba} \\
\mathrm{Ce} \\
\mathrm{Co} \\
\mathrm{Cr} \\
\mathrm{Cu}\end{array}$ & $\begin{array}{r}100 \\
150 \\
50 \\
200 \\
70 \\
15 \\
100 \\
50 \\
200 \\
70 \\
30 \\
0 \\
1000 \\
300 \\
50 \\
5 \\
200\end{array}$ & $\begin{array}{r}200 \\
100 \\
70 \\
700 \\
70 \\
15 \\
30 \\
30 \\
300 \\
0 \\
30 \\
0 \\
300 \\
150 \\
20 \\
2 \\
150\end{array}$ & $\begin{array}{r}300 \\
0 \\
70 \\
500 \\
150 \\
10 \\
0 \\
10 \\
100 \\
10 \\
30 \\
5 \\
500 \\
300 \\
20 \\
2 \\
100\end{array}$ & $\begin{array}{r}300 \\
0 \\
50 \\
500 \\
150 \\
10 \\
0 \\
0 \\
150 \\
70 \\
50 \\
15 \\
200 \\
200 \\
15 \\
1.5 \\
30\end{array}$ & $\begin{array}{r}70 \\
0 \\
30 \\
1500 \\
500 \\
7 \\
0 \\
0 \\
300 \\
0 \\
50 \\
0 \\
200 \\
200 \\
7 \\
0 \\
7\end{array}$ \\
\hline
\end{tabular}

\begin{tabular}{|c|c|c|c|c|c|}
\hline \multicolumn{6}{|c|}{ CIPW norms } \\
\hline$q$ & $\begin{array}{l}5.7 \\
5.7\end{array}$ & $\bar{z}$ & - & - & - \\
\hline or & $\begin{array}{l}5.7 \\
3.2\end{array}$ & $6 . \overline{5}$ & $8 . \overline{3}$ & $5 . \overline{4}$ &.$\overline{94}$ \\
\hline $\mathrm{ab}$ & 35.5 & 19.6 & 27.1 & 32.2 & 26.2 \\
\hline an & .2 & 22.0 & 14.8 & 21.2 & 23.0 \\
\hline ne & - & - & $\begin{array}{l}7.8 \\
9.8\end{array}$ & 8 & \\
\hline $\begin{array}{l}\text { di-wo } \\
\text { di-en }\end{array}$ & - & $\begin{array}{l}4.6 \\
3.6\end{array}$ & $\begin{array}{l}9.8 \\
5.2\end{array}$ & $\begin{array}{l}5.8 \\
3.6\end{array}$ & $\begin{array}{l}9.8 \\
6.4\end{array}$ \\
\hline $\begin{array}{l}\text { a-en } \\
\text { di-fs }\end{array}$ & - & .5 & 4.2 & $\begin{array}{l}3.0 \\
1.8\end{array}$ & $\begin{array}{l}6.4 \\
2.7\end{array}$ \\
\hline hy-en & 10.6 & 15.2 & - & 3.8 & 16.8 \\
\hline hy-fs & 14.7 & 2.2 & - & 1.9 & 7.0 \\
\hline ol-fo & - & 8.2 & 6.3 & 11.4 & 2.8 \\
\hline ol-fa..... & - & 1.3 & 5.6 & 6.3 & 1.3 \\
\hline $\mathrm{mt}$ & 1.0 & 7.3 & 1.7 & .96 & .8 \\
\hline il ......... & 4.6 & 4.2 & 4.9 & 1.6 & .44 \\
\hline ap $\ldots$ & 1.2 & .83 & .92 & .26 & 1 \\
\hline cc $\ldots$ & 13.6 & .18 & 1.9 & .32 & 14 \\
\hline
\end{tabular}

NOTE.-Name and location of specimens:

75-62 Variolitic spilite. Klamath River Road, $\mathrm{SE}^{1 / 4}$, sec. 16, T.46 N., R.7 W., Hornbrook quadrangle.

20-66 Fragmental basalt. Paradise Craggy, Hornbrook quadrangle.

16-61 Spilite. NW1/4, sec. 5, T.45 N., R.8 W., Condrey Mtn. quadrangle.

2-64 Spilite. Klamath River Road, SW1/4, sec. 18, T.46 N., R.6 W., Hornbrook 132-64 Fragmental Fragmental basalt. Empire Creek, S. part NW1/4, sec. 36, T.42 N., R.8 W.

anhedral relict phenocrysts that are clouded in some specimens. Faint twinning lamellae are preserved in some specimens, but in many the original phenocrysts have been partly to wholly recrystallized to a mosaic of anhedral untwinned grains with the outlines of the original phenocrysts preserved. Plagioclase in the groundmass of some specimens preserves the outlines of original lath-shaped crystals, but most of the groundmass feldspar has been recrystallized to anhedral granules intergrown with and penetrated by acicular actinolite.

Pale-green actinolite, the most abundant mineral in these rocks, occurs as matted needles in the groundmass, as anhedral matted porphyroblasts, and as euhedral to subhedral fibrous masses (uralite) that pseudomorph original pyroxene phenocrysts. Uncommonly, original pyroxene is preserved in the central part of actinolite phenocrysts. West of Cayuse Gulch, in rocks that were probably originally tuffaceous, actinolite has a subparallel orientation.

Chlorite is common but not abundant. It is intergrown with plagioclase and actinolite in the groundmass of the metavolcanic rocks. West of Cayuse Gulch, pale-brown biotite in small flakes occurs with actinolite and plagioclase. Chlorite partly replaces biotite and, to a lesser extent, actinolite, hence is probably a retrograde mineral.

Clinozoisite and epidote are not abundant in any of these rocks, and they are absent from some specimens. Clinozoisite tends to be more abundant. Both occur as small granules in the groundmass, as grains enclosed in feldspar, and in a few places, as veinlets.

Sphene, ubiquitous as a minor accessory, occurs as very small grains or clusters of grains and gray translucent masses. It may or may not be accompanied by fine opaque dust and grains.

Carbonate is fairly common as irregular and lenticular masses, some of which are clearly relict amygdules.

\section{CHEMICAL COMPOSITION}

Chemical analyses of five representative specimens of metavolcanic rocks from the Klamath River canyon and vicinity in the Condrey Mountain and Hornbrook quadrangles are presented in table 4; they are classified according to their plotted positions on diagrams of $\mathrm{SiO}_{2}$ relative to $\mathrm{Na}^{2} \mathrm{O}_{2}$ and $\mathrm{CaO}$ (fig. 5). They have the composition of spilite and basalt, except for no. 132-64, which, owing to its higher $\mathrm{SiO}_{2}$ content, is andesite. They have a moderate water content relative to terrestrial basaltic rocks, an expectable feature considering their low-grade metamorphic state. These rocks have a lower content of $\mathrm{CaO}$ than ocean floor basalts (Cann, 1971; Kay and others, 1970); $\mathrm{Na}_{2} \mathrm{O}$ is distinctly higher than in basalt in samples 16-61, 2-64, and 75-64, about the same in sample 20-66. $\mathrm{K}_{2} \mathrm{O}$ is higher than in basalt, except for sample 132-64 (table 4). Total iron (as $\mathrm{FeO}$ ) and $\mathrm{Al}_{2} \mathrm{O}_{3}$ are about the same. The higher $\mathrm{Na}_{2} \mathrm{O}$ content and lower $\mathrm{CaO}$ are possibly the result of spilitization of basaltic lavas. Amounts of $\mathrm{TiO}_{2}$ and $\mathrm{P}_{2} \mathrm{O}_{5}$ are greater than in ocean floor basalts in samples 20-66 and 16-61, about the same in 2-64, and markedly lower in the andesite, sample 132-64.

Sample 75-62, a variolitic spilite, is somewhat unusual because of its high $\mathrm{CO}_{2}$ content. The rock has abundant carbonate in microscopic vesicles; the low 

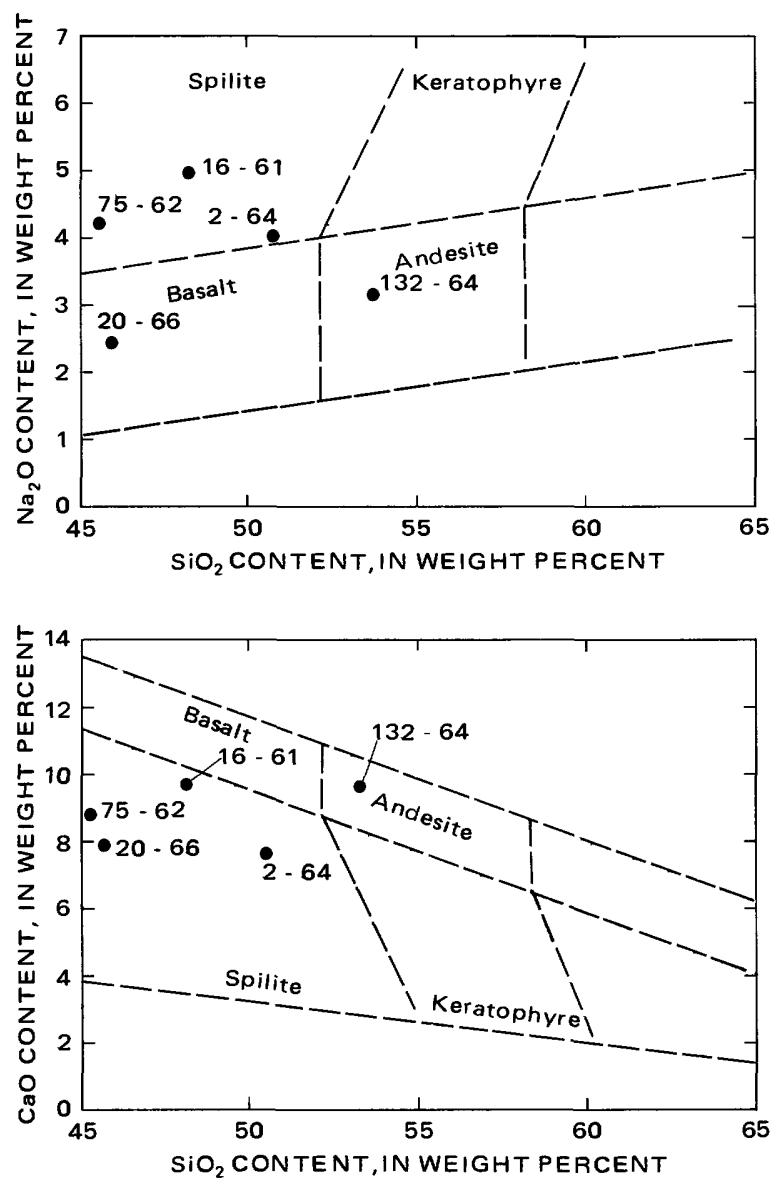

Figure 5.- $\mathrm{Na}_{2} \mathrm{O}$ and $\mathrm{CaO}$ relative to $\mathrm{SiO}_{2}$ for metavolcanic rocks from Condrey Mountain and Hornbrook quadrangles (from data given in table 4). Classification from Hamilton (1963, p. 71).

$\mathrm{Fe}_{2} \mathrm{O}_{3}$ and high $\mathrm{FeO}$ content combined with relatively low $\mathrm{CaO}$ suggest that not all the carbonate is as calcite, and may include a considerable component of siderite.

\section{METASEDIMENTARY ROCKS}

The metasedimentary rocks are predominantly dark-gray to black argillite and slaty argillite; they contain a few thin interbeds of siliceous or cherty argillite and microcrystalline recrystallized chert and a very few thin lenticular beds of marble. Some of the argillaceous rocks are also calcareous.

East of approximately the longitude of Cayuse Gulch, the metasedimentary rocks are composed mainly of microcrystalline quartz, muscovite, and carbon. Very pale green to colorless chlorite is a fairly common accessory mineral, and hazy albitic feldspar and actinolite are locally present. Calcite is abundant in some layers.

West of Cayuse Gulch, the rocks are similar, but pale-brown biotite is a fairly common constituent in- stead of chlorite, which, where present, appears to be mainly a retrograde mineral that replaces biotite and actinolite; some layers are rich in calcite; others are dark and carbonaceous. Some layers that probably were tuffaceous are made up of a foliated matrix of actinolite, biotite, and granular plagioclase that wraps around relict plagioclase phenocrysts.

Near the mouth of Empire Creek, gray, massive to thick-bedded, sugary-grained microcrystalline quartzite crops out on both sides of the river. These rocks, probably recrystallized chert, are composed mainly of very finegrained to microcrystalline quartz; some specimens contain minor amounts of biotite; others contain parallel-oriented fibers of tremolite. Finegrained to microcrystalline quartz-biotite schist occurs as thin interbeds in some of the quartzite, probably representing originally argillaceous layers.

\section{AGE AND CORRELATION}

These metavolcanic and metasedimentary rocks are continuous with similar rocks in the central and southern Klamath Mountains that are part of the western Paleozoic and Triassic belt (Irwin, 1960, 1966).Similar rocks in southern Oregon were included in the Applegate Group of Late(?) Triassic age (Wells and others, 1949; Wells, 1956; Wells and Peck, 1961). In the southern Klamath Mountains, the belt includes fossiliferous limestone lenses of Permian and Triassic age (Irwin, 1972), and a limestone lense northeast of Yreka that has yielded Late Permian (Ochoan)fossils (Elliott, 1971). Discovery that some of the cherts in this belt contain Triassic and Jurassic radiolarians has been used as evidence that at least some of the limestone bodies are blocks floating in a Jurassic melange (Irwin, 1977; Irwin and others, 1977).

\section{STUART FORK FORMATION}

A small area of Stuart Fork Formation shown in the southern part of the region of figure 2 is an outlier of a thrust plate that occurs farther south in the Yreka-Fort Jones area (fig. 1) (Hotz, 1973). It is the north end of a small klippe that overlies metavolcanic and metasedimentary rocks of the western Paleozoic and Triassic belt.

The rocks are contorted siliceous phyllite and phyllitic quartzite composed of fine-grained recrystallized quartz and discontinuous plicated micaceous laminae composed of muscovite, pale biotite, and chlorite. Locally there are small amounts of actinolitic phyllite. Where these rocks occur to the south in Fort Jones and Yreka quadrangles, they commonly contain lawsonite and a blue sodic amphibole. 
The Stuart Fork has been correlated with rocks in the western Paleozoic and Triassic belt (Davis and Lipman, 1962; Davis and others, 1965; Davis, 1968). A Middle to Late Jurassic age has been postulated for metamorphism of the Stuart Fork on the basis of limited potassium-argon age determinations ranging from 133 to $158 \mathrm{~m}$.y. for samples collected in the southern Klamath Mountains (Lanphere and others, 1968). In the Yreka-Fort Jones area, age determinations of approximately 220 m.y. (Middle Triassic) were obtained on mica from three samples of blueschist (Hotz and others, 1977).

\section{AMPHIBOLITE FACIES}

The Condrey Mountain Schist is bordered on the east, north, and west by a terrane in which the rocks are of the amphibolite facies (figs. 1, 2). The higher grade metamorphic rocks structurally overlie the Condrey Mountain Schist along a moderate to steeply dipping fault. In contrast to the schist, which is devoid of plutonic rocks and has only a few small bodies of serpentinite, the terrane underlain by rocks of the amphibolite facies contains many bodies of ultramafic rock and some gabbroic and dioritic plutons. Approximately equal amounts of amphibolite and metasedimentary rocks occur in this terrane in the Condrey Mountain and western Hornbrook quadrangles. Rocks of the two types are to some extent interbedded, but extensive tracts are predominantly of one or the other (fig. 2).

Most of the amphibolite is foliated, but some of it is massive and resembles a metavolcanic rock (fig. $6 \mathrm{~A}$ ), even to retaining a porphyritic texture (fig. $6 B$ ). Two kinds of amphibolite, foliated and nonfoliated, are described here and are shown separately on the geologic map (fig. 2).

\section{FOLIATED AMPHIBOLITE}

Megascopically, the foliated amphibolite ranges from very fine to medium grained and is commonly lineated. In many specimens, the foliation is made apparent by segregation of plagioclase and mafic minerals into parallel layers. In exposures that have no visible layering and no micas, the schistosity may not be visible; under the microscope, a preferred orientation of hornblende that defines a planar structure can usually be seen. Many amphibolites have a lineation made apparent by parallel orientation of hornblende prisms that lie in the plane of foliation.

The texture is crystalloblastic and the rocks are mostly fine grained (fig. 6C,D). Equant xenoblastic plagioclase is intergrown with subhedral to euhedral nematoblastic hornblende. Plagioclase grains range in size from approximately 0.02 to $0.1 \mathrm{~mm}$, most commonly around $0.06 \mathrm{~mm}$; hornblende prisms are 0.05 to $0.5 \mathrm{~mm}$ long, most commonly about 0.1 with a lengthto-width ratio of 2.5:1 to 4:1. Commonly, the rocks have a more or less well-developed layering or streaking caused by alternating plagioclase and hornblende-rich layers. Most laminae are very narrow, generally a millimeter or less in width, discontinuous or lenticular. Recrystallization has essentially obliterated original textures and structures, but in many specimens relict phenocrysts of plagioclase and hornblende can be identified. The original plagioclase phenocrysts are completely recrystallized to a polyhedral mosaic with subrectangular boundaries. Some specimens are porphyroblastic. The metacrysts are most commonly coarser hronblende grains, but porphyroblasts of plagioclase occur.

Foliated amphibolite has a simple mineralogy. Its principal components are hornblende and plagioclase, characteristic of the almandine-amphibolite facies. Sphene and an opaque black metallic mineral are common minor accessories. Other minerals that may be present, usually in subordinate amounts, are epidote group minerals, clinopyroxane, mica (usually biotite), quartz, and calcite.

Plagioclase is somewhat more calcic than in the nonfoliated amphibolite. It ranges from approximately $\mathrm{An}_{25}$ to $\mathrm{An}_{55}$, in most specimens it is $\mathrm{An}_{30-35}$. The composition in pyroxene-bearing amphibolites is more calcic, in the range $\mathrm{An}_{40-55}$. Most of the grains of plagioclase are clear and inclusion-free. Commonly they are untwinned; a few may show twinning lamellae under crossed-polarized light. Some may show simple progressive zoning; most do not.

Hornblende in thin section is almost always strongly colored and commonly has a blue-green pleochroic color in the $\mathrm{Z}$ direction; from specimen to specimen, it may range from green to brown. Hornblende that has a brown pleochroism commonly occurs in amphibolite specimens that contain pyroxene and a more calcic plagioclase; the pyroxene and more calcic plagioclase are indicative of a slightly higher metamorphic grade.

The pyroxene in some of the amphibolite is colorless to very pale green nonpleochroic diopside that occurs as anhedral granules intergrown with plagioclase and hornblende, generally occurring in laminae accompanied by plagioclase with subordinate hornblende. In a few specimens, pyroxene was observed to occur as anhedral porphyroblasts.

Very minor to trace amounts of biotite occur in some

FIGURE 6.- Photomicrographs of amphibolite. $A, B$, Nonfoliated variety showing randomly oriented hornblende and relict porphyritic texture. $C, D$, Foliated variety showing welldeveloped preferred orientation of hornblende. 

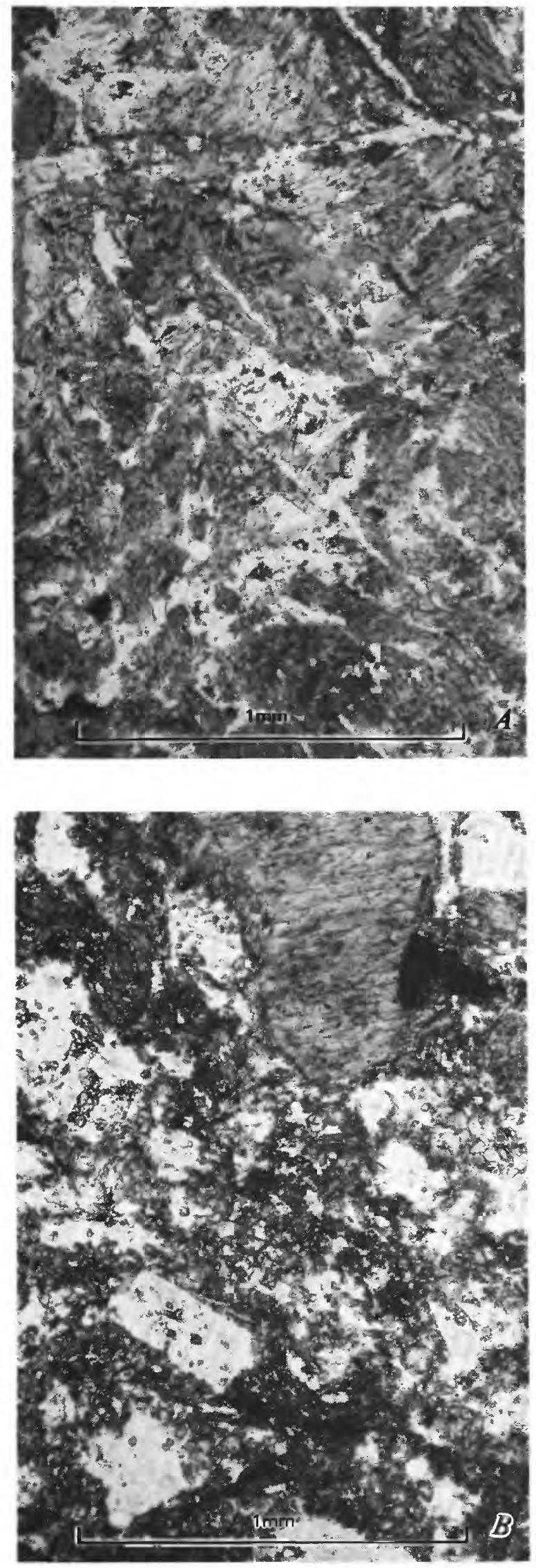
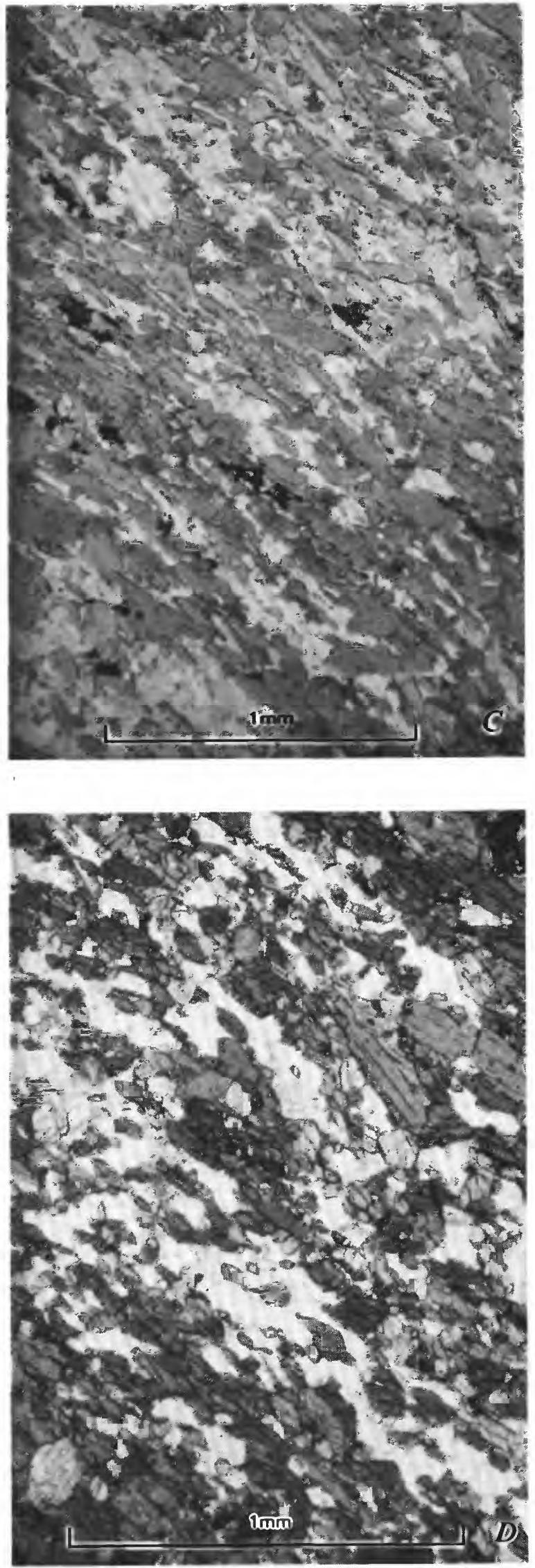
of the amphibolite, but it is not usually present. Anhedral, droplike granules of sphene are common. Sphene may range from trace amounts to as much as 4 or 5 percent volumetrically and commonly is as abundant as 1.5 to 2 percent; it is absent from some specimens. Grains of unidentified black opaque metallic grains, probably magnetite, are ubiquitous, ranging from trace amounts to as much as 1.5 percent. Quartz, calcite, and chlorite may be present in minor quantities in some specimens. Garnet is notably absent from the foliated amphibolite. Only one specimen, obtained from float, contained pink andraditic garnet.

Typically, either epidote or clinozoisite is absent from the foliated amphibolite. Some specimens contain trace to very minor amounts of epidote, and some contain clinozoisite that, in each sample examined, is retrograde from the alteration of plagioclase.

\section{NONFOLIATED AMPHIBOLITE}

Nonfoliated amphibolite occurs on the south and east borders of the amphibolite terrane, largely between the areas of foliated amphibolite and the terrane occupied by metavolcanic and metasedimentary rocks of the western Paleozoic and Triassic belt.

Adjacent to the large serpentinite body in the southeastern part of the amphibolite terrane and in small areas in the southern part, the mafic rocks have a mineralogy characteristic of the amphibolite facies yet they retain many original textural features of metavolcanic rocks. In general, the rocks are massive and unfoliated, though completely recrystallized, except locally where they may have a fine-grained compositional layering possibly inherited from originally tuffaceous rocks. Characteristically, there is no welldeveloped preferred orientation of the minerals. These rocks are characterized by the occurrence together of plagioclase and hornblende and the absence or occurrence in very minor amounts of epidote group minerals; hence they are of the almandine-amphibolite facies.

Plagioclase in these rocks ranges in composition from approximately $\mathrm{An}_{25}$ to $\mathrm{An}_{35}$. It occurs as small anhedral crystalloblastic grains in the groundmass intergrown with hornblende, as granoblastic pseudomorphs of original phenocrysts, and as unrecrystallized subhedral to euhedral relict phenocrysts. The recrystallized grains are seldom twinned. Some of the relict phenocrysts are polysynthetically twinned. Composition of the relict phenocrysts is apparently the same as the recrystallized plagioclase in the groundmass.

Hornblende rather than actinolite is the amphibole of these rocks. In thin section the hornblende is light colored but slightly darker than the actinolite of the greenschist facies rocks. Characteristically, its pleochroism is: (x), colorless to pale greenish yellow; (y), pale yellowish green; $(\mathrm{z})$, pale green, commonly with a faint blue tinge to pale blue green. On a $\beta-2 \mathrm{~V} \alpha$ plot (fig. 7), these amphiboles lie in the hornblende field. Unlike actinolitic amphibole, they are not fibrous in habit, but rather are well-formed prismatic. The hornblende is randomly oriented and commonly matted; in some specimens, a slight tendency toward parallel alignment is apparent. Some of the hornblende is pseudomorphous after original pyroxene phenocrysts. Uncommonly, some of the hornblende pseudomorphs have a small central core of relict augite.

Most of these rocks contain no epidote-group minerals; a few specimens contain minor amounts of either clinozoisite or epidote, minerals that seem not to occur together in the rock. Epidote is possibly more common. Some of the clinozoisite occurs with chlorite in veinlets that cut the rock. The presence of epidote minerals may indicate that some of these rocks are transitional between the upper greenschist facies and the amphibolite facies. In some, it may indicate retrograde metamorphic reactions.

Sphene, apatite, and a black opaque mineral which is presumably ilmenite-magnetite are common minor accessories in these rocks. The sphene occurs as very small anhedral droplike granules. The black opaque minerals are fine grained and may occur as fine granules, irregular skeletal and spongy bodies, or fine rodlike grains. Apatite commonly occurs as long slender needles and as stubby subhedral crystals.

Pale-brown biotite occurs in minor to trace amounts

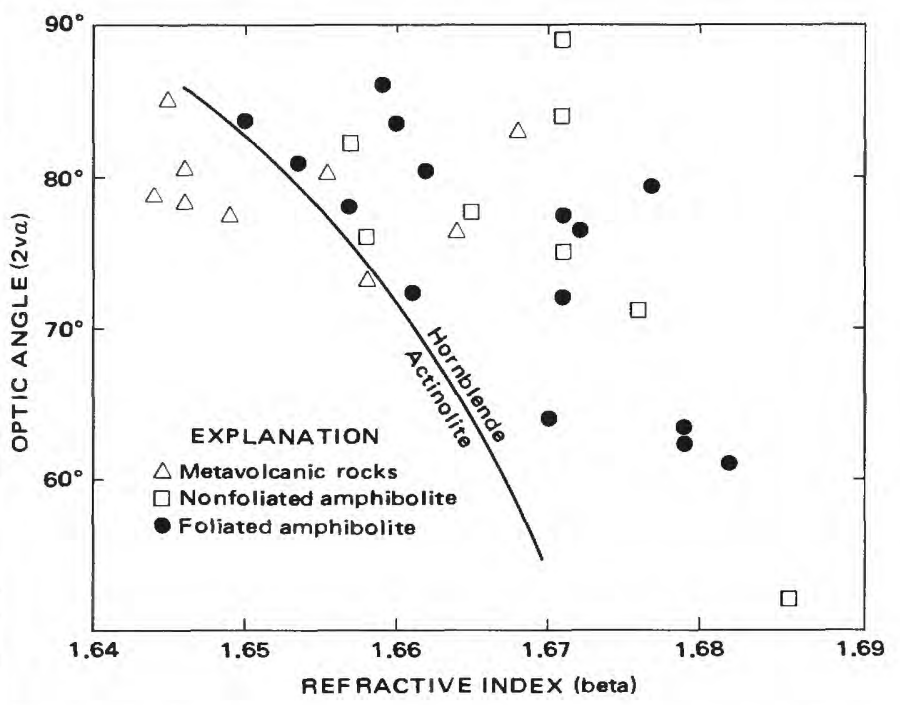

FIGURE 7.-Diagram of amphiboles in metavolcanic rock and amphibolite from Condrey Mountain and Hornbrook quadrangles. Boundary line from Holdaway (1965). 
in some specimens but it is not a common accessory. Pale chlorite, which is present in a few specimens, is absent from most specimens. In the few samples examined, it could not be certainly determined whether it is a relict or a retrograde mineral. Calcite, which is very uncommon, occurs in a few specimens as veinlets and as ovoid bodies that probably are relict amygdules.

\section{CHEMICAL COMPOSITION}

It is apparent from analyses of six samples of foliated amphibolite and six of nonfoliated amphibolite (table 5) that chemically they are practically the same, the main difference being the lower water content of the more strongly metamorphosed foliated amphibolite. The average content of the oxides is very similar; that of the total alkalis and $\mathrm{TiO}_{2}$ is identical. On an AFM plot (fig. 4), both amphibolites occupy essentially the same field; the foliated variety is somewhat more restricted. The close similarity in composition between the two varieties strongly suggests that rocks of the same type were involved and that the metamorphism was essentially isochemical except for the loss of $\mathrm{H}_{2} \mathrm{O}$ in the formation of the foliated amphibolite.

Relative to metabasalt and spilite of the less strongly metamorphosed volcanic rocks east and south of the amphibolite terrane (fig. 2; table 4), the $\mathrm{SiO}_{2}$ content of amphibolite (table 5) has a narrow range and $\mathrm{H}_{2} \mathrm{O}$ and $\mathrm{CO}_{2}$ are low. The amphibolites have a more constant total alkali content, the average $\mathrm{K}_{2} \mathrm{O}$ is lower, and the $\mathrm{CaO}$ is notably higher. A contrast in $\mathrm{TiO}_{2}$ content is apparent: in all the analyses of amphibolite, $\mathrm{TiO}_{2}$ is less than 2 percent; in three of the metavolcanic rock samples, $\mathrm{TiO}_{2}$ content is greater than 2 percent. The AFM plot (fig. 4) illustrates the somewhat narrower compositional range of the amphibolite relative to the metavolcanic rocks.

\section{METASEDIMENTARY ROCKS}

Metasedimentary rocks are interbedded with amphibolite in the Condrey Mountain quadrangle. They occur in a belt east of Beaver Creek and east of the north-northeast leg of the Klamath River between Little Humbug Creek and Beaver Creek. The belt extends northward from the northern boundary of the Vesa Bluffs pluton to the northern boundary of the quadrangle and beyond into Oregon, becoming dominant over amphibolite northward. These metasedimentary rocks underlie the large eastern body of serpentinite and largely overlie the foliated amphibolite, although there may be some intertonguing of the two units. The contact between the metasedimentary rocks and the underlying amphibolite is occupied at many places by a thin tabular body of serpentinite. Another belt of metasedimentary rocks occurs east of the serpentinite belt, extending from Lumgrey Creek to the east fork of Beaver Creek, where it joins with the northern area of metasedimentary rocks. Some smaller lenticular bodies of metasedimentary rock are interbedded with the amphibolite.

The metasedimentary rocks are mainly siliceous schist and phyllite, minor quartzite, and subordinate amounts of marble in discontinuous thin beds and lenses.

The siliceous rocks are most commonly dark gray, less commonly light, fine grained, and finely foliated. Individual minerals cannot usually be recognized megascopically, although porphyroblastic grains of pink garnet are easily recognized where they occur. Where fine-grained biotite is abundant, it imparts a dusky red-purple coloration. In places where the rocks attain medium grain size, individual constituents are more easily seen.

Under the microscope, these rocks are seen to be crystalloblastic and finely foliated with a welldeveloped planar structure, both compositional and as produced by the parallel orientation of platy minerals. As the average grain size is commonly about 0.05 , very fine, most of these rocks are more properly classed as phyllites. Medium-grained schistose varieties in which the grain size is $1-4 \mathrm{~mm}$ are much less common.

A common variety is quartz-biotite phyllite; quartzbiotite schist is less common. Some are quartzofeldspathic rocks, the feldspar generally being an untwinned sodic plagioclase; potassium feldspar may occur in some varieties. Other phases commonly present include muscovite, pink almandine garnet, and retrograde chlorite. An opaque mineral, probably magnetite, tourmaline, and apatite are ubiquitous minor accessories, and sphene is present in some. $\mathrm{Al}$ mandine garnet commonly forms small porphyroblasts, conspicuous in hand specimens. Muscovite also forms porphyroblasts, commonly poikiloblastic, but typically recognizable only in thin section. A variety of quartzo-feldspathic phyllite observed in thin section but not recognized megascopically contains hornblende in addition to biotite.

Another common metasedimentary rock type is dark gray to black, commonly sooty appearing, very fine grained, and phyllitic. Lighter quartzose laminae and lenses are commonly visible. The microscope shows that these rocks are composed of fine polyhedral quartz, colorless mica, and abundant graphite. Biotite and fine colorless fibers of tremolite may be present in small amounts. Fine-grained pyrite was recognized in some specimens.

Fine-grained finely foliated quartzite is somewhat 
TABLE 5.-Chemical and spectrographic analyses, CIPW norms, and modes of amphibolite

[Chemical analyses by rapid methods; analysts, P. L. D. Elmore, S. D. Botts, Gillison Chloe, Lowell Artis, James Kelsey, Hezekiah Smith, and J. L. Glenn. Semiquantitative spectrographic analyses: samples 3, 5, 6, 9, 12 by W. B. Crandell; 2,4 by Chris Heropoulos; $1,7,8,11,19$ by Carolyn Pickett. Sample localities shown in fig. 2]

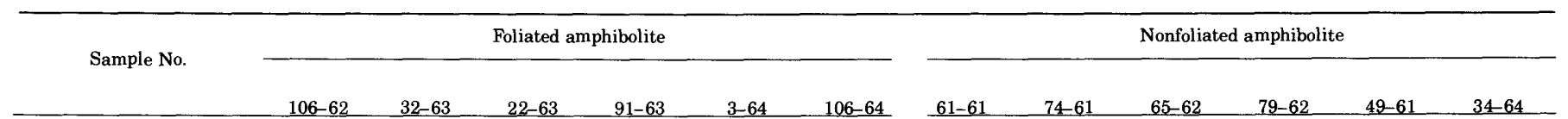

Chemical analyses (weight percent)

\begin{tabular}{|c|c|c|c|c|c|c|c|c|c|c|c|c|c|}
\hline $\mathrm{SiO}_{2}$ & - - - - & 49.1 & 49.1 & 49.5 & 49.6 & 50.4 & 50.9 & 46.2 & 48.4 & 49.2 & 49.7 & 49.8 & 50.0 \\
\hline $\mathrm{Al}_{2} \mathrm{O}_{3}$ & - - & 14.0 & 16.4 & 18.0 & 17.8 & 13.8 & 13.8 & 17.2 & 20.1 & 16.1 & 18.8 & 14.8 & 14.8 \\
\hline $\mathrm{Fe}_{2} \mathrm{O}_{3}$ & 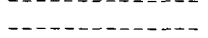 & 5.0 & 3.4 & 1.6 & 1.0 & 7.1 & 1.6 & 1.8 & 2.8 & 1.0 & 2.4 & 1.6 & .71 \\
\hline $\mathrm{FeO}$. & n & 8.8 & 8.0 & 6.6 & 8.5 & 9.7 & 8.5 & 8.1 & 7.6 & 7.1 & 8.7 & 9.2 & 10.9 \\
\hline $\mathrm{MgO}$ & $---1+---1--$ & 5.0 & 4.9 & 4.0 & 5.5 & 6.8 & 7.5 & 6.8 & 4.5 & 7.7 & 4.6 & 7.9 & 6.7 \\
\hline $\mathrm{CaO}$ & $-----1--1--4$ & 11.3 & 11.3 & 15.2 & 10.7 & 9.7 & 9.7 & 11.3 & 10.0 & 11.9 & 10.6 & 8.7 & 8.4 \\
\hline $\mathrm{Na}_{2} \mathrm{O}$ & $---1--1--\infty$ & 2.2 & 3.4 & 2.2 & 3.6 & 3.6 & 3.3 & 4.0 & 2.1 & 2.7 & 2.4 & 3.7 & 4.2 \\
\hline $\mathrm{K}_{2} \mathrm{O}$ & --1-- & .70 & .53 & .45 & 1.2 & .40 & .63 & .64 & .64 & .80 & .44 & .47 & .14 \\
\hline $\mathrm{H}_{2} \mathrm{O}-$ & $---1-+-1--1$ & .04 & .05 & .06 & .02 & .08 & .09 & .06 & .36 & .10 & .21 & .12 & .04 \\
\hline $\mathrm{H}_{2} \mathrm{O}+$ & - - - & .93 & .76 & .56 & .74 & .92 & 1.2 & 1.4 & 2.3 & 1.3 & 1.6 & 1.4 & 1.3 \\
\hline $\mathrm{TiO}_{2}$ & - - - - - - & .20 & 1.6 & .51 & 1.0 & 1.8 & 1.7 & .99 & .63 & 1.3 & .70 & 1.1 & 1.9 \\
\hline $\mathrm{P}_{2} \mathrm{O}_{5}$ & 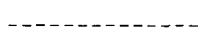 & .11 & .19 & .13 & .12 & .16 & .21 & .13 & .21 & .16 & .12 & 1.0 & .22 \\
\hline $\mathrm{MnO}$ & - - - - - & .24 & .20 & .15 & .13 & .20 & .16 & .20 & .17 & .12 & .15 & .18 & .17 \\
\hline $\mathrm{CO}_{2}$ & - n- & $<.05$ & $<.05$ & .21 & .06 & .05 & .05 & 1.3 & $<.05$ & .16 & $<.05$ & $<.05$ & .11 \\
\hline Total _ & 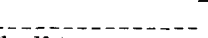 & 100 & 100 & 99 & 100 & 100 & 99 & 100 & 100 & 100 & 100 & 99 & 100 \\
\hline $\mathrm{Sp} \mathrm{Gr}$ & bulk) & 3.09 & - & 3.01 & 3.02 & 3.02 & 2.99 & 2.99 & 2.97 & 3.02 & 3.08 & & 3.00 \\
\hline \multicolumn{14}{|c|}{ Semiquantitative spectrographic analyses (ppm) } \\
\hline B & 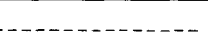 & - & - & - & - & - & - & - & 30 & - & 30 & - & - \\
\hline $\mathrm{Ba}$ & 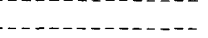 & 100 & 50 & 200 & 70 & 20 & 100 & 200 & 300 & 150 & 150 & 70 & 70 \\
\hline Co & 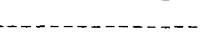 & 30 & 50 & 30 & 50 & 30 & 70 & 70 & 30 & 50 & 30 & 50 & 30 \\
\hline $\mathrm{Cr}$ & - & 200 & 300 & 50 & 500 & 200 & 500 & 700 & 30 & 500 & 30 & 500 & 700 \\
\hline $\mathrm{Cu} \ldots$ & - & 30 & 50 & 300 & 50 & 30 & 70 & 150 & 200 & 50 & 150 & 20 & 50 \\
\hline $\mathrm{Ga}$ & 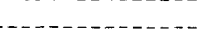 & 20 & 15 & 10 & 15 & 10 & 10 & 15 & 15 & 10 & 15 & 15 & 10 \\
\hline $\mathrm{Ni} \ldots$ & - - - - - & 70 & 100 & 30 & 100 & 70 & 20 & 300 & 30 & 100 & 30 & 150 & 100 \\
\hline $\mathrm{Pb}_{-\ldots}$ & $-1-1-1-1-1-1$ & 20 & & & & & 70 & 15 & 500 & 5 & 50 & 15 & $\ldots$ \\
\hline Sc $\ldots$ & 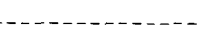 & 30 & 50 & 30 & 50 & 30 & 50 & 50 & 30 & 30 & 30 & 50 & 30 \\
\hline Sn _.. & - & - & - & - & - & 5 & 15 & 15 & 30 & - & - & - & - \\
\hline $\mathrm{Sr}$ & 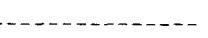 & 300 & 200 & 500 & 500 & 100 & 150 & 1500 & 1000 & 150 & 1000 & 700 & 100 \\
\hline$V_{-1}$ & 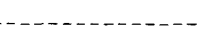 & 300 & 200 & 200 & 200 & 200 & 200 & 300 & 300 & 200 & 300 & 300 & 200 \\
\hline$Y_{-\ldots}$ & n & 50 & 50 & 10 & 30 & 30 & 30 & 30 & 15 & 15 & 15 & 30 & 20 \\
\hline $\mathrm{Yb}_{---}$ & 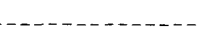 & 5 & 5 & 1 & 3 & 3 & 3 & 3 & 2 & 1.5 & 1.5 & 3 & 2 \\
\hline $\mathrm{Zr}$ & $\ldots$ & 150 & 100 & $1 \overline{5}$ & 50 & 50 & 50 & 70 & $5 \overline{0}$ & 50 & 20 & 70 & 50 \\
\hline \multicolumn{14}{|c|}{ CIPW norms (weight percent) } \\
\hline$q-\ldots$ & 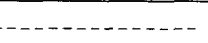 & 4.7 & - & 0.35 & - & $\longrightarrow$ & - & - & 2.2 & - & 1.6 & -1 & - \\
\hline or & - & 4.1 & 3.1 & 2.7 & 7.1 & 2.4 & 3.7 & 3.8 & 3.8 & 4.7 & 2.6 & 2.8 & .83 \\
\hline$a b \ldots$ & 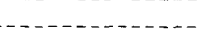 & 18.7 & 28.8 & 18.6 & 23.9 & 30.5 & 27.9 & 21.8 & 17.9 & 22.8 & 20.3 & 31.6 & 35.5 \\
\hline an $\ldots$ & - n- & 26.4 & 28.0 & 37.9 & 28.9 & 20.3 & 21.0 & 27.1 & 43.8 & 29.5 & 39.1 & 22.6 & 21.1 \\
\hline wo & 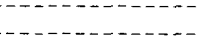 & 11.6 & 11.3 & 14.7 & 9.6 & 11.0 & 10.6 & 8.3 & 2.0 & 11.5 & 5.2 & 8.5 & 7.7 \\
\hline en & 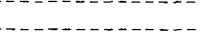 & 12.5 & 7.5 & 10.0 & 4.8 & 11.0 & 14.6 & 4.6 & 11.3 & 8.7 & 11.4 & 7.4 & 6.0 \\
\hline fa $\ldots$ & $-1-1-1-1-1$ & 9.2 & 5.9 & 10.2 & 4.7 & 8.8 & 9.2 & 3.3 & 11.0 & 4.7 & 13.1 & 5.3 & 6.0 \\
\hline fo --- & 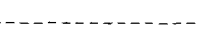 & $\longrightarrow$ & 3.3 & - & 6.3 & 4.1 & 2.9 & 8.6 & $\longrightarrow$ & 7.3 & - & 8.8 & 7.5 \\
\hline fa ... & - & - & 2.9 & - - & 6.7 & 3.6 & 2.0 & 6.8 & - & 4.3 & - & 6.9 & 8.2 \\
\hline mt $\ldots$ & n & 7.3 & 4.9 & 2.3 & 1.5 & 3.0 & 2.3 & 2.6 & 4.1 & 1.5 & 3.4 & 2.3 & 1.0 \\
\hline il ... & - & 3.8 & 3.0 & .97 & 1.9 & 3.4 & 3.3 & 1.9 & 1.2 & 2.5 & 1.3 & 2.1 & 3.6 \\
\hline ap ... & 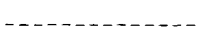 & .74 & .45 & .31 & .28 & .38 & .50 & .31 & .50 & .38 & .28 & .24 & .52 \\
\hline cc _... & 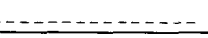 & - & - & .48 & .14 & .11 & .11 & 2.9 & - & .36 & - - & - & .25 \\
\hline \multicolumn{14}{|c|}{ Modal analyses (volume percent) } \\
\hline Plagio & lase & $11\left(\mathrm{~A}_{411}\right)$ & $33\left(\mathrm{~A}_{37}\right)$ & $34\left(\mathrm{~A}_{55}\right)$ & $\left(\mathrm{A}_{35}\right)$ & $35\left(A_{35}\right)$ & $34\left(A_{38}\right)$ & $10\left(\mathrm{~A}_{35}\right)$ & 36 & $16\left(\mathrm{~A}_{32}\right)$ & 23 & $23\left(\mathrm{An}_{25}\right)$ & 38(An32) \\
\hline Hornb & ende & 82 & 51 & 37 & - & 58 & 60 & 78 & 56 & 60 & 46 & 73 & 73 \\
\hline $\begin{array}{l}\text { Clinop } \\
\text { Biotite }\end{array}$ & roxene & - & 13 & 21 & 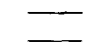 & 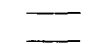 & & 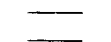 & 3 & - & -5 & - & {[} \\
\hline Sphen & & 2 & 1.5 & .7 & L & 5 & 2 & 2 & $\stackrel{0}{-}$ & .6 & - & 1 & - \\
\hline Apatit & & 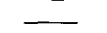 & $\mathrm{tr}$ & .1 & - & - & .5 & & $\underline{-}$ & & - & $<.5$ & - \\
\hline Opaqu & & 1 & .5 & .3 & 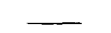 & 2 & .2 & - & 2 & 2 & 1 & - & 4 \\
\hline Epidot & -clinozoisite & 4 & .9 & 7 & - & - & .7 & 2 & $\operatorname{tr}$ & 20 & 25 & 3 & .3 \\
\hline Carbor & $\begin{array}{l}\text { ate } \\
\text { e }\end{array}$ & - & - & .4 & - & $\operatorname{tr}$ & $\overline{3}$ & 4 & 2 & 5 & $\overline{4}$ & 1 & 3 \\
\hline Sericit & & - & - & - & - & tr & $\ddot{2}^{3}$ & 3 & 2 & $i^{3}$ & $\stackrel{4}{ }$ & $\stackrel{1}{-}$ & .0 \\
\hline
\end{tabular}

106-62 South side Klamath River, NE1/4, sec. 6, T.46 N., R.8 W Condrey Mountain quadrangle.

$32-63$
$22-63$
North part NE $1 / 4$, , sec. 17, T. 47 N., R. 8 W. Condrey Mountain quadrangle.

91-63 South central part SW1/4, sec. 31, T. 48 N. R. 8 W. Condrey Mountain quadrangle.

3-64 McKinney Creek, SE1/4, sec. 16, T. 46 N., R. 9 W. Condrey Mountain quadrangle.
$106-64$ Beaver Creek, line between sec. 24, T. 47 N., R. 9 W., and sec. 19, T. 47 N., R. 8 W. Condrey Mtn. quadrangle.

61-61 SE $\mathrm{SE}^{1 / 4}$, sec. 17, T. 46 N., R. 8 W. Condrey Mountain quadrangle.

65-62 Lumgrey Creek, N part sec. 35 , T. 47 N., R. 8 W. Hornbrook quadrangle

79-62 South side Klamath River, SE1/4, sec. 1, T. 46 N., R. 8 W. Hornbrook quadrangle.

34-64 South side Klamath River, SE'/4, sec. 4, T. 46 N., R. 8 W. Condrey Mountain quadrangle. 
less common but nevertheless frequently observed. Fine $(0.01-0.1 \mathrm{~mm})$ polyhedral crystalloblastic quartz is the principal constituent, but colorless mica is ubiquitous and minor pale biotite may be present. Tourmaline, fine-grained opaque magnetite, and apatite are usually present. Stilpnomelane was observed in several thin sections of quartzite, where it commonly has a sheaflike radiating habit with the blades lying across the rock foliation. One specimen of quartzite contained a blue amphibole, probably crossite, and epidote in laminae with magnetite. An uncommon variety is calcareous quartzite composed of intergrown quartz and calcite accompanied by minor amounts of tremolite.

The thin beds and lenses of marble are composed predominantly of crystolloblastic calcite that ranges from fine to coarse grained. The marble is generally quite pure but it may contain some impurities, seldom more than about 10 percent. These include quartz, white mica, and some carbonaceous material. At one place an impure marble has been metamorphosed to a silica-carbonate rock composed of coarse diopside poikilitically enclosing calcite and a few blades of tremolite.

The only metasedimentary rock analyzed is a sample of garnetiferous quartz biotite phyllite; the analysis is presented in table 6 .

\section{AGE}

Rocks herein assigned to the amphibolite facies in the Seiad Valley quadrangle have been considered pre-Mesozoic by Rynearson and Smith (1940); Medaris (1966) tentatively correlated them with the Salmon

TABLE 6.-Chemical and spectrographic analysis and CIPW norm of quartz-biotite phyllite

[Chemical analysis by rapid methods; analysts: P. L. D. Elmore, S. D. Botts, Gillison Chloe, Lowell Artis, and Hezekiah Smith. Spectrographic analysis by Carolyn Pickett. Sample locality shown in fig. 2]

\begin{tabular}{|c|c|c|}
\hline $\begin{array}{l}\text { Chemical analysis } \\
\text { (weight percent) }\end{array}$ & $\begin{array}{c}\text { Semiquantitative } \\
\text { spectrographic } \\
\text { analysis }(\mathrm{ppm}) \\
\end{array}$ & $\begin{array}{c}\text { CIPW } \\
\text { norms } \\
\text { (percent) }\end{array}$ \\
\hline $\mathrm{SiO}_{2} \ldots$ & 700 & -16.6 \\
\hline $\mathrm{Al}_{2} \mathrm{O}_{3}$ & $\mathrm{Be}$ & 5.1 \\
\hline 1.0 & 500 & -14.2 \\
\hline $\mathrm{FeO}$ & -10 & -28.0 \\
\hline $\mathrm{MgO} \ldots$ & -20 & -7.3 \\
\hline $\mathrm{CaO}$ & -70 & en. \\
\hline $\mathrm{Na}_{2} \mathrm{O}$ & $\mathrm{Ga}_{--}$ & -15.7 \\
\hline $\mathrm{K}_{2} \mathrm{O}$ & $\mathrm{La}$ & $\mathrm{mt}$ \\
\hline $\mathrm{H}_{2} \mathrm{O}_{-} .10$ & -50 & il . \\
\hline$\ldots 1.2$ & $\mathrm{Ni}_{-}$ & ap $\ldots \ldots$ \\
\hline-1.7 & $\mathrm{~Pb}_{--}$ & \\
\hline $\begin{array}{ll}\ldots .93 \\
\ldots . .\end{array}$ & -20 & \\
\hline $\mathrm{MnO} \ldots \ldots$ & $\mathrm{Sr}$ & \\
\hline $\mathrm{CO}_{2}$ & $\mathrm{~V}$ & \\
\hline Total $\bar{\ldots}$ & $\mathrm{Yb}$ & \\
\hline $\begin{array}{l}\text { Powder } \\
\quad \text { density _-_- } 2.90\end{array}$ & $\mathrm{Zr}$ & \\
\hline
\end{tabular}

NOTE.-Quartz-plagioclase-biotite-almandine phyllite (CM-58-61), Road, south side Klamath River, SW1/4, sec. 4, T. 46 N., R. 8 W. and Abrams Formations of the south-central Klamath Mountains. Wells (1956) interpreted them to be metamorphic equivalents of the Upper Triassic Applegate Group, and Hotz (1967) considered them to be the metamorphic equivalent of the western Paleozoic and Triassic belt.

Isotope analysis of hornblende from two samples of amphibolite from the Condrey Mountain quadrangle yielded ages of 148 and 146 m.y. (Lanphere and others, 1968). These ages suggest metamorphism during the Jurassic rather than an older metamorphic episode represented by the Salmon and Abrams Formations.

\section{MAFIC AND ULTRAMAFIC ROCKS}

\section{SERPENTINITE}

In both the Condrey Mountain and Seiad Valley quadrangles, there is a direct relation between the distribution of ultramafic rocks and the occurrence of amphibolite-grade rocks (figs. 1,2). Bodies of ultramafic rocks occur widely in the areas of amphibolite but are absent from the areas of weakly metamorphosed volcanic and sedimentary rocks. A few small tabular bodies of serpentinite are infolded with the Condrey Mountain Schist. The association of ultramafic rocks with amphibolite-grade metamorphism continues south of Seiad Valley quadrangle in the Scott Bar quadrangle in the Marble Mountains (Pratt, 1964) and persists northward into Talent quadrangle, Oregon (Wells, 1956).

The amphibolite-grade rocks in the Condrey Mountain quadrangle are in general structurally below the main ultramafic body, but many small discontinuous tabular bodies of serpentinite occupy ridges and summits in the area. Tabular concordant bodies of serpentinite are interleaved with the metemorphic rocks and in places are found at the contact between metasedimentary rocks and amphibolite. In the Seiad Valley quadrangle, the ultramafic rocks apparently occur beneath as well as above the higher grade rocks (Medaris, 1966; Barrows, 1969). A characteristic structural feature of the ultramafic bodies throughout the area of high-grade metamorphism is their concordance with the large-scale planar structure of the metamorphic rocks. Discordant dikelike bodies are very rare. The typically curvilinear form of many of the serpentinite bodies, especially in the Condrey Mountain quadrangle, is produced by erosion of gently dipping thin concordant serpentinite bodies.

The ultramafic rocks include harzburgite and dunite and their serpentinized derivatives. Surbordinate amounts of wehrlite and lherzolite occur in an ultramafic complex in the Tom Martin Creek area of 
southeastern Seiad Valley and northeastern Scott Bar quadrangles (Barrows, 1969). Harzburgite and its serpentinized equivalent are by far the most common ultramafic rocks. In the Condrey Mountain quadrangle, probably more than 90 percent of the ultramafic rocks are serpentinized, even the large body north of the Klamath River in the eastern part of the quadrangle. Much of the serpentinite is not sheared, even the smaller bodies, except locally along faults and some contacts. In many places, however, thin tabular bodies of serpentinite in the metamorphic terrane are converted to schistose talc-actinolite rock.

Serpentinite in the Condrey Mountain quadrangle has not been extensively studied petrographically; several specimens have been examined in thin section and some X-ray studies were made. Primary minerals of the ultramafic rock are seldom preserved; in all the specimens examined, only relict olivine was seen. Some of the serpentinite is composed of a web of chrysotile-lizardite mixture, minor brucite, and very minor amounts of olivine; some consists entirely of antigorite. Most commonly the serpentinite is composed of antigorite with minor amounts of chrysotilelizardite. Magnetite, formed by the release of iron from olivine during serpentinization, is a common secondary mineral in all the serpentinite. A carbonate mineral, probably magnesite, is present in small amounts in some specimens, and talc and tremolite may be present in minor amounts. Antigorite is the metamorphic equivalent of lizardite, chrysotile, and brucite (Page, 1966; Trommsdorff and Evans, 1974). Presumably these antigoritic serpentinites were formed by the metamorphism of previously serpentinized ultramafic rocks. It is not certain if the metamorphic episode was the same as that which produced rocks of the amphibolite facies that enclose the serpentinite.

At many places in a narrow zone adjacent to the contact with the enclosing metamorphic rocks, the serpentinite has been converted to fine-grained tremolite rock and talc-tremolite schist. One of the largest of these bodies is south of the Klamath River east of Little Humbug Creek. In this body, the rock is schistose and very fine grained and is composed of variable amounts of talc, tremolite, and magnesite. Within it are fine-grained unsheared nodular masses of talc and magnesite. When seen in thin section, serpentinite that megascopically appears to be unaltered adjacent to talc-carbonate rock shows considerable replacement by talc and carbonate.

The alteration of serpentinite to talc-carbonate rock (table 8 ) is accomplished almost entirely by carbondioxide metasomatism accompanied by loss of water (Chidester, 1962). Talc-tremolite schist (table 7) is possibly formed from serpentinite by the addition of
TABLE 7.-Chemical analyses, in weight percent, of serpentinite and magnesian schist

[Rapid rock analyses by P. L. D. Elmore, Samuel Botts, and Lowell Artis. Localities shown in fig. 2]

\begin{tabular}{|c|c|c|c|c|}
\hline Sample No. & $39-61$ & $83-64$ & $82-64$ & $76-64$ \\
\hline $\begin{array}{l}\mathrm{SiO}_{2} \\
\mathrm{Al}_{2} \mathrm{O}_{3} \\
\mathrm{Fe}_{2} \mathrm{O}_{3} \\
\mathrm{FeO} \\
\mathrm{MgO} \\
\mathrm{CaO} \\
\mathrm{Na}_{2} \mathrm{O} \\
\mathrm{K}_{2} \mathrm{O} \\
\mathrm{H}_{2} \mathrm{O} \\
\mathrm{H}_{2} \mathrm{O}_{+} \\
\mathrm{TiO}_{2} \\
\mathrm{P}_{2} \mathrm{O}_{5} \\
\mathrm{MnO} \\
\mathrm{CO}_{2}\end{array}$ & $\begin{array}{c}37.5 \\
.46 \\
3.1 \\
2.7 \\
39.2 \\
.12 \\
.12 \\
.00 \\
.66 \\
11.9 \\
.05 \\
.02 \\
.22 \\
3.5 \\
\end{array}$ & $\begin{array}{c}38.5 \\
.40 \\
4.2 \\
2.6 \\
35.3 \\
2.7 \\
.12 \\
.00 \\
.72 \\
11.4 \\
.03 \\
.02 \\
.17 \\
3.8 \\
\end{array}$ & $\begin{array}{c}17.7 \\
.40 \\
.89 \\
5.1 \\
39.2 \\
.22 \\
.05 \\
.00 \\
.03 \\
1.5 \\
.03 \\
.02 \\
.22 \\
34.8 \\
\end{array}$ & $\begin{array}{c}56.2 \\
2.8 \\
.81 \\
4.9 \\
23.5 \\
7.1 \\
.30 \\
.11 \\
.14 \\
3.7 \\
.07 \\
.04 \\
.17 \\
.09 \\
\end{array}$ \\
\hline $\begin{array}{c}\text { Total } \\
\text { Sp gr (bulk) }\end{array}$ & $\begin{array}{l}100 \\
2.66\end{array}$ & $\begin{array}{l}100 \\
2.53\end{array}$ & $\begin{array}{l}100 \\
2.98\end{array}$ & $\begin{array}{l}100 \\
2.90\end{array}$ \\
\hline
\end{tabular}

NOTE.-39-61 Serpentinite with minor magnesite, sec. 10, T. 46 N., R. 8 W. 83-64 Serpentinite with relict olivine, magnetite, and minor talc, $\mathrm{S}$. Edge sec. 8, T. $46 \mathrm{~N}$, R. $8 \mathrm{~W}$

82-64 Unsheared talc-carbonate rock $S$. edge sec. 8, T. 46 N., R. 8 W.

76-64 Tremolite-talc schist, extreme $\mathrm{NE}^{1 / 4}$ sec. 7 , T. 46 N., R. 8 W.

TABLE 8.-Chemical analyses, in weight percent, illustrating metasomatic reaction at serpentinite-amphibolite contact

[Rapid rock analysis by P. L. D. Elmore, Samuel Botts, and Lowell Artis. Sample localities shown in fig. 2]

\begin{tabular}{|c|c|c|c|c|c|}
\hline \multirow{2}{*}{ Sample no. } & \multicolumn{2}{|c|}{ Amphibolite } & \multicolumn{2}{|c|}{$\begin{array}{l}\text { Clinozoisite } \\
\text { metasomatite }\end{array}$} & \multirow{2}{*}{$\frac{\text { Serpentinite }}{121-64}$} \\
\hline & $124-64$ & $125-64$ & $126-64$ & $122-64$ & \\
\hline $\mathrm{SiO}_{2} \ldots$ & 57.8 & 55.4 & 36.6 & 42.6 & 40.7 \\
\hline $\mathrm{Al}_{2} \mathrm{O}_{3}$ & 13.4 & 12.6 & 21.8 & 23.2 & 1.6 \\
\hline $\mathrm{Fe}_{2} \mathrm{O}_{3}$ & .63 & .86 & 3.6 & 3.5 & 4.6 \\
\hline $\mathrm{FeO}$ & 6.7 & 8.4 & 10.2 & 3.7 & 2.7 \\
\hline MgO & 6.0 & 6.9 & 6.9 & 2.5 & 37.8 \\
\hline $\mathrm{CaO}_{2}$ & 7.6 & 7.6 & 13.7 & 21.9 & .09 \\
\hline $\mathrm{Na}_{2} \mathrm{O}$ & 5.6 & 4.5 & .25 & .25 & .05 \\
\hline $\mathrm{K}_{2} \mathrm{O}_{\ldots}$ & .35 & .10 & .08 & .09 & .00 \\
\hline $\mathrm{H}_{2} \mathrm{O}-\ldots$ & .09 & .18 & .11 & .09 & .41 \\
\hline $\mathrm{H}_{2} \mathrm{O}+\ldots$ & .81 & 1.7 & 4.5 & 1.4 & 11.6 \\
\hline $\mathrm{TiO}_{2}$ & .64 & 1.1 & 1.3 & .33 & .02 \\
\hline $\mathrm{P}_{2} \mathrm{O}_{5}$ & .07 & .11 & .04 & 09 & .02 \\
\hline $\mathrm{MnO}$ & .15 & .21 & .21 & .19 & .11 \\
\hline $\mathrm{CO}_{2}$ & $<.05$ & .09 & .11 & .08 & .12 \\
\hline$-\ldots$ & 100 & 100 & 99 & 100 & 100 \\
\hline Sp gr (bulk) .....- & 2.88 & 2.89 & 3.17 & 322 & 2.72 \\
\hline
\end{tabular}

NOTE.-All specimens located in SW/4 sec. 19, T. 47 N., R. 8 W.

124-64 Retrograded amphibolite $2 \mathrm{~m}$ from contact (albite-hornblende-sphene).

125-64 Retrograded amphibolite $-1.5 \mathrm{~cm}$ from contact (albite-chloriteactinolite-sphene).

126-64 Clinozoisite metasomatite at contact (clinozoisite-chlorite-tremolitesphene).

122-64 Clinozoisite metasomatite at contact (clinozoisite-minor chloritetremolite-sphene-trace of garnet).

121-64 Serpentinite $1 \mathrm{~m}$ above contact.

alumina and silica from the adjacent schist or amphibolite accompanied by loss of magnesia and water from the ultramafic rock. The metamorphism that produced the talc-tremolite rocks probably postdates the earlier regional metamorphism. At many places it ap- 
pears to be related to faulting between the higher grade country rocks and serpentinite.

Contact effects of the ultramafic rocks are not apparent in most places. Where such effects have been observed, they are generally not extensive. Adjacent to an ultramafic complex in Seiad Valley quadrangle, amphibolite is recrystallized to pyroxene granulite and hornblende-pyroxene granulite; yet such contact metamorphic effects are absent from another peridotite body in the same area (Medaris, 1966). One very localized occurrence of pyroxene granulite less than a meter in width occurs adjacent to a thin serpentinite body in northern Condrey Mountain quadrangle. Barrows (1969) noted that greenschist facies rocks have been converted to amphibolite next to an ultramafic complex in southeastern Seiad Valley quadrangle.

Another kind of metamorphic phenomenon was observed in the Condrey Mountain quadrangle where amphibolite adjacent to a thin concordant serpentinite body has retrograded to a greenschist facies albitechlorite-actinolite rock as much as $2 \mathrm{~m}$ from the contact, and a clinozoisite-tremolite rock has been formed at the contact. This is a postmetamorphic metasomatic reaction involving movement of $\mathrm{Al}_{2} \mathrm{O}_{3}$ and $\mathrm{CaO}$ from the amphibolite toward the contact with concomitant loss of alkalis and some $\mathrm{SiO}_{2}$ in the same direction. The main contribution from the serpentinite side is a slight increase in $\mathrm{H}_{2} \mathrm{O}$ (table 8; fig. 8).

\section{GABBRO AND PYROXENITE}

Numerous small bodies of gabbro and pyroxenite are associated with serpentinite in an area of amphibolite facies rocks north of Klamath River and east of Beaver Creek. These mafic bodies have forms similar to the serpentinite bodies. They occur with the metasedimentary rocks and amphibolite and as apparently transgressive bodies in serpentinite, although they may be in part interlayered with the serpentinite. These bodies are composed of both gabbro and pyroxenite; gabbro is more abundant, the pyroxenite generally occuring as localized bodies with indefinite boundaries within the gabbro. More specifically, the rocks are quartz-bearing hornblende gabbro with subordinate pyroxene and hornblende clinopyroxenite.

The gabbro is a mesocratic to melanocratic (CI 43-73) fine- to medium-grained rock composed predominantly of hornblende and plagioclase. Clinopyroxene may or may not be present as a minor constituent; most commonly, it occurs as relicts enclosed by hornblende. The plagioclase is labradorite $\left(\mathrm{An}_{60}\right)$, and may be zoned as sodic as andesine $\left(\mathrm{An}_{40}\right)$; in many specimens, the plagioclase is gray and saus-

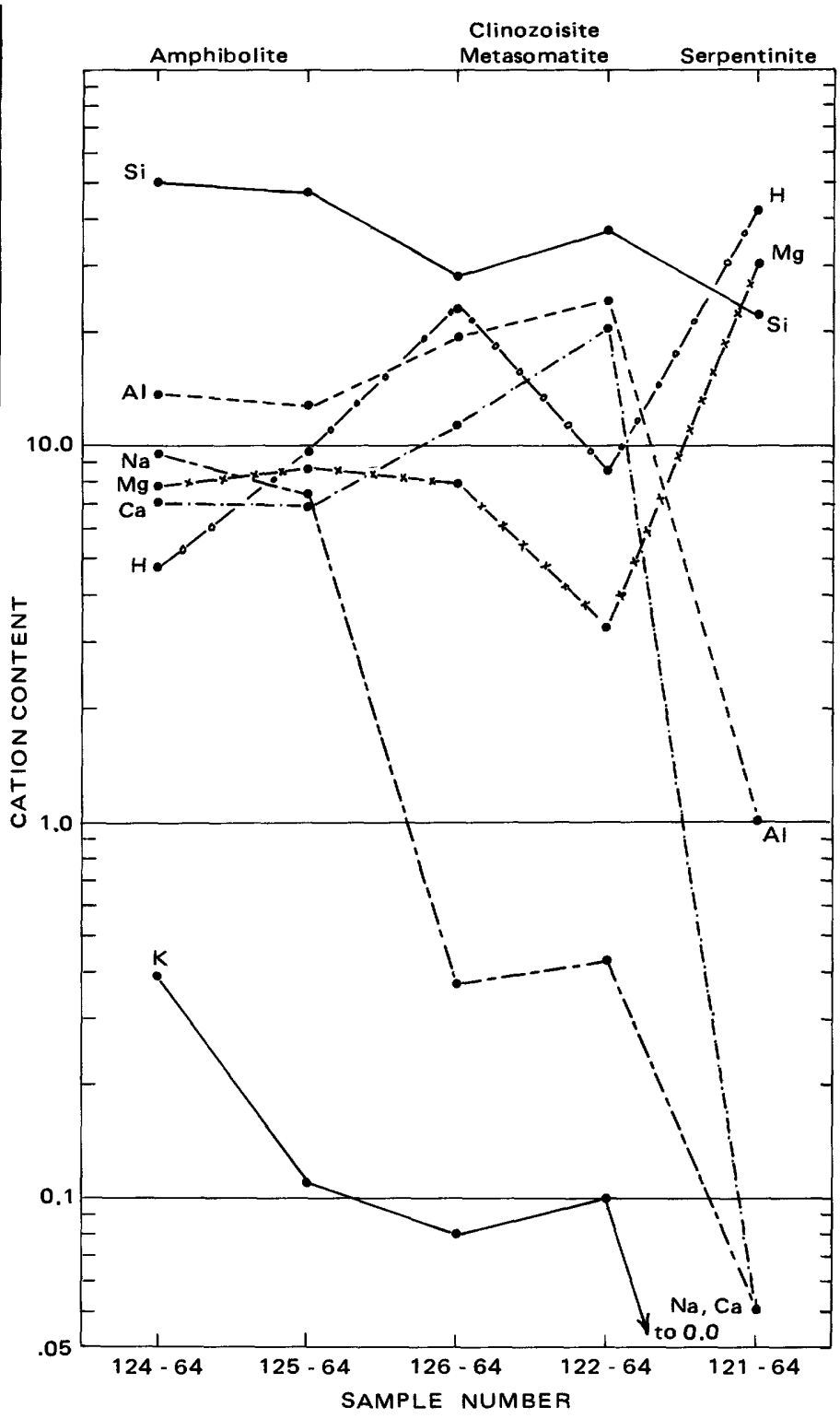

FIGURE 8.-Change in cation content of amphibolite at contact with serpentinite.

suritized; in some, the plagioclase may be mostly replaced by clinozoisite. Small quantities of biotite occur in some specimens. Some specimens contain as much as 8 percent quartz. Besides clinozoisite, late-stage alteration products include small amounts of chlorite and sericite. A somewhat unusual variety of gabbro in the Condrey Mountain quadrangle contains as much as 15 percent clinopyroxene, relict hypersthene amounting to 0.5 percent, and 13 percent biotite in addition to hornblende, plagioclase, and a trace of quartz. Two analyses of quartz-bearing gabbro are presented in table 9, Nos. 52-63 and 59-63. One of them (59-63), a porphyritic gabbro intermediate between gabbro and hornblende pyroxenite, is nearly 60 percent amphibole, nearly 10 percent clinopyroxene, and nearly 20 percent 
TABLE 9.-Chemical analyses, CIPW norms, and modes of gabbro, pyroxenite, and pyroxene quartz diorite

[Chemical analyses by rapid methods; analysts: P. L. D. Elmore, S. D. Botts, Gillison Chloe, Lowell Artis, and Hezekiah Smith. Sample localities shown in fig. 2]

\begin{tabular}{|c|c|c|c|c|c|}
\hline \multicolumn{6}{|c|}{ Chemical analyses (weight percent) } \\
\hline Sample No. & $27-6 \overline{3}$ & $52-63$ & $59-63$ & $53-63$ & $26-63$ \\
\hline $\begin{array}{l}\mathrm{SiO}_{2} \\
\mathrm{Al}_{2} \mathrm{O}_{3} \\
\mathrm{Fe}_{2} \mathrm{O}_{3} \\
\mathrm{FeO} \\
\mathrm{MgO} \\
\mathrm{CaO} \\
\mathrm{Na}_{2} \mathrm{O} \\
\mathrm{K}_{2} \mathrm{O} \\
\mathrm{H}_{2} \mathrm{O}- \\
\mathrm{H}_{2} \mathrm{O} \mathrm{O} \\
\mathrm{TiO}_{2} \\
\mathrm{P}_{2} \mathrm{O}_{5} \\
\mathrm{MnO}\end{array}$ & $\begin{array}{c}49.5 \\
13.8 \\
1.0 \\
9.8 \\
8.6 \\
11.4 \\
1.6 \\
.44 \\
.12 \\
1.2 \\
1.4 \\
.60 \\
.21\end{array}$ & $\begin{array}{c}50.9 \\
14.8 \\
2.5 \\
9.0 \\
6.6 \\
9.5 \\
2.4 \\
1.2 \\
.23 \\
1.3 \\
1.2 \\
.35 \\
.21\end{array}$ & $\begin{array}{c}52.1 \\
10.7 \\
1.2 \\
6.4 \\
11.7 \\
12.6 \\
1.7 \\
.82 \\
.34 \\
1.1 \\
.78 \\
.16 \\
.15\end{array}$ & $\begin{array}{c}53.6 \\
4.6 \\
.92 \\
5.7 \\
15.5 \\
15.5 \\
.73 \\
.58 \\
.20 \\
.76 \\
.30 \\
.16 \\
.15\end{array}$ & $\begin{array}{r}57.9 \\
14.9 \\
1.2 \\
6.2 \\
6.1 \\
7.9 \\
2.5 \\
1.2 \\
.16 \\
.52 \\
.84 \\
.34 \\
.13\end{array}$ \\
\hline $\begin{array}{l}\text { Total } \\
\text { Sp. gr. (bulk) }\end{array}$ & $\begin{array}{c}100 \\
2.95\end{array}$ & $\begin{array}{c}100 \\
2.93\end{array}$ & $\begin{array}{l}100 \\
2.98\end{array}$ & $\begin{array}{l}99 \\
2.98\end{array}$ & 100 \\
\hline \multicolumn{6}{|c|}{ CIPW norms (percent) } \\
\hline $\begin{array}{l}\text { q } \\
\text { or } \\
\text { ab } \\
\text { an } \\
\text { di-wo } \\
\text { di-en } \\
\text { di-fs } \\
\text { hy-en } \\
\text { hy-fs } \\
\text { ol-fo-fol } \\
\text { ol-fa- } \\
\text { mt } \\
\text { il } \\
\text { ap }\end{array}$ & $\begin{array}{r}1.8 \\
2.6 \\
13.5 \\
29.2 \\
9.8 \\
5.5 \\
3.9 \\
15.9 \\
11.3 \\
\overline{-} \\
1.44 \\
2.6 \\
1.4\end{array}$ & $\begin{array}{r}1.3 \\
7.1 \\
20.3 \\
26.1 \\
7.8 \\
4.2 \\
3.3 \\
12.2 \\
9.5 \\
\\
3.6 \\
2.3 \\
.83\end{array}$ & $\begin{array}{r}\overline{4.8} \\
14.4 \\
19.1 \\
17.7 \\
12.2 \\
4.1 \\
16.4 \\
5.5 \\
.4 \\
.1 \\
1.7 \\
1.5 \\
.38\end{array}$ & $\begin{array}{r}1.7 \\
3.4 \\
6.2 \\
7.6 \\
28.5 \\
20.8 \\
5.1 \\
17.8 \\
4.4 \\
\\
1.3 \\
.57 \\
.38\end{array}$ & $\begin{array}{r}11.6 \\
7.1 \\
21.2 \\
25.9 \\
4.6 \\
2.7 \\
1.8 \\
12.5 \\
8.2 \\
\\
1.7 \\
1.6 \\
.80\end{array}$ \\
\hline \multicolumn{6}{|c|}{ Modal analyses (volume percent) } \\
\hline $\begin{array}{l}\text { Quartz } \\
\text { Plagioclase } \\
\text { Hornblende } \\
\text { Clinopyroxene } \\
\text { Orthopyroxene } \\
\text { Biotite } \\
\text { Sphene } \\
\text { Opaque } \\
\text { Chlorite } \\
\text { Clinoz-epidote } \\
\text { Sericite } \\
\text { Apatite }\end{array}$ & $\begin{array}{l}0.3 \\
40 \\
48 \\
4 \\
-.6 \\
-.7 \\
6 \\
-\operatorname{tr} \\
-\end{array}$ & $\begin{array}{l}3 \\
31 \\
48 \\
- \\
- \\
3 \\
3 \\
3 \\
10 \\
2 \\
-\end{array}$ & $\begin{array}{c}2 \\
19 \\
58 \\
9 \\
- \\
- \\
\operatorname{tr}^{3} \\
1 \\
7 \\
3 \\
-\end{array}$ & $\begin{array}{l}\overline{7} \\
60 \\
32 \\
- \\
-.2 \\
-.4 \\
= \\
=\end{array}$ & $\begin{array}{r}12 \\
49 \\
4 \\
15 \\
8 \\
16 \\
-.1 \\
-. \\
- \\
-.1\end{array}$ \\
\hline
\end{tabular}

NOTE.-27-63 Hornblende-pyroxene gabbro south part SW1/4, sec. 3, T47 N., R.8 W 52-63 Altered hornblende-quartz bearing gabbro west central part, $\mathrm{SW}^{1 / 4} \mathrm{sec}$ 34, T. 48 N., R. 8 W

59-63 Porphyritic hornblende-pyroxene-quartz bearing gabbro $\mathrm{SW}$ part $\mathrm{NE}^{1 / 4}$ 53-63 Hornblende clinopyroxenite dike $\mathrm{N}$ part $\mathrm{SE}^{1 / 4}$ sec. $33, \mathrm{~T}, 48 \mathrm{~N} . \mathrm{R} .8 \mathrm{~W}$ 26-63 Biotite-hornblende-pyroxene quartz diorite $\mathrm{SW}^{1 / 4} \mathrm{SE}^{1 / 4}$ sec. 3, T. 47 N, R. $8 \mathrm{~W}$

plagioclase. An analysis of hornblende gabbro with a trace of quartz and a small amount of clinopyroxene is given in table 9, No. 27-63.

Hornblende pyroxenite is commonly a grayish-green medium-grained hypidiomorphic to allotriomorphic granular rock, locally with a subporphyritic "spotted" appearance. It has a color index above 90 and is mainly composed of hornblende and clinopyroxene with less than 10 percent plagioclase. The plagioclase is consistently saussuritized. Hornblende commonly amounts to about 60 percent and encloses-poikilitically in some specimens-colorless clinopyroxene. Typically, the hornblende is pleochroic from pale brown to colorless; some is pale green. Sphene and apatite are present in amounts less than 1 percent. Chlorite, which amounts to less than 1 percent, partly replaces hornblende. Analysis of a sample of hornblende clinopyroxenite (53-63) is given in table 9 .

\section{AGE}

There is no direct evidence for the age of the serpentinite except for its occurrence as pendants in the Ashland and the Vesa Bluffs granitic plutons; the pendants indicate that emplacement of the ultramafic rocks occurred before intrusion and crystallization of the granitic rocks in Late Jurassic time. The close association of serpentinite with rocks of the amphibolite facies suggests that both ultramafic and metemorphic rocks were involved in the episode of deformation and metamorphism. The Seiad ultramafic complex of Medaris (1966) and the Tom Martin ultramafic complex of Barrows (1969) were emplaced tectonically at high temperatures during a period of deformation and regional metamorphism. In the Condrey Mountain quadrangle, the presence of numerous small discontinuous bodies of serpentinite scattered throughout the terrane of amphibolite rock facies is suggestive of a melange. The association of serpentinite with amphibolite derived from basaltic rocks accompanied in places by quartzite that may represent original chert suggests that these rocks may be part of a dismembered ophiolite suite. This concept is strengthened by the occurrence in the same terrane of gabbro and pyroxenite bodies similar in form and habit to the serpentinite. A Permian and Triassic ophiolite has been recognized in the Preston Peak area (Snoke, 1977), approximately 65 $\mathrm{km}$ west of the Condrey Mountain quadrangle. This ophiolite has been displaced and now rests in thrust fault contact on metasedimentary rocks of the Late Jurassic Galice Formation. Indirect evidence suggests that the ultramafic rocks in the Condrey Mountain quadrangle belong to an ophiolite of Permian and (or) Triassic age. In the Seiad Valley quadrangle, the ultramafic rocks may represent peridotite emplaced as hot diapirs.

\section{PLUTONIC ROCKS}

Several bodies of plutonic rock are intrusive into rocks of the amphibolite terrane and the lower grade metavolcanic and metasedimentary rocks. None intrude the Condrey Mountain Schist.

\section{PYROXENE QUARTZ DIORITE AND GRANODIORITE}

An irregular body of plutonic rock ranging from quartz diorite to granodiorite in which pyroxene is the most abundant characterizing accessory crops out in the northeast Condrey Mountain quadrangle southwest of the Ashland pluton. Its extent eastward in the Hornbrook quadrangle is unknown. A body of hornblende gabbro lies between it and the Ashland pluton, which intrudes the gabbro. Although the gab- 
bro and pyroxene quartz diorite are in contact, their relative ages are uncertain. Field relations suggest that the bodies are gradational into one another.

The rock is mesocratic (C.I. 30-40) fine grained with an hypidiomorphic granular texture. Unlike the gabbro and hornblende pyroxenite associated with ultramafic rocks and amphibolite, the plagioclase is clear, unaltered, and zoned normally with cores of labradorite $\left(A n_{60}\right)$ and rims of andesine $\left(A n_{40}\right)$. The rock contains about 12 percent quartz and may have as much as 10-13 percent potassium feldspar, although the analyzed sample did not contain any. Subhedral pyroxene is the chief mafic mineral, amounting to 12 percent to nearly 19 percent in the specimens examined microscopically. The pyroxene is colorless augite and hypersthene. Green hornblende ( 4 to approximately 12 percent) forms reaction rims on the pyroxene; biotite (approximately 7-16 percent), commonly with a large central grain of magnetite, occurs as isolated irregular-shaped flakes or as partial replacements of hornblende. Apatite, sphene, and black opaques are common minor accessories. An analysis of a specimen of hornblende biotite pyroxene quartz diorite (No. 26-63) is given in table 9 .

A potassium-argon age of $152 \mathrm{~m}$.y. has been obtained (M. A. Lanphere, oral commun., 1970) on biotite from a sample of the pyroxene quartz diorite represented by analysis 5 , table 9 . This date was obtained by rerunning a sample that earlier (Lanphere and others, 1968, table 4, No. 31) yielded an age of 133 m.y.

\section{GRANITIC ROCKS}

Granitic rocks in the Condrey Mountain and Hornbrook quadrangles include the Vesa Bluffs pluton in southern Condrey Mountain and southwestern Hornbrook quadrangles and the Ashland pluton in northeastern Condrey Mountain and the northwestern Hornbrook quadrangles, California and the greater part in Oregon. The Vesa Bluffs body is relatively small, $19 \mathrm{~km}^{2}$, whereas the Ashland pluton- $400 \mathrm{~km}^{2}$, has batholithic proportions. The plutonic rocks include hornblende gabbro and diorite, quartz diorite, granodiorite, and minor quantities of alaskitic rock. Many plutons of similar size and composition occur elsewhere in the Klamath Mountains (Hotz, 1971).

The Vesa Bluffs pluton is a narrow elongate pluton oriented east-west in southern Condrey Mountain and southwestern Hornbrook quadrangles. In the Condrey Mountain quadrangle, the pluton is a southwarddipping tabular body with amphibolite facies rocks in the footwall and a roof of weakly metamorphosed volcanic and sedimentary rocks. In the Hornbrook quadrangle, it loses its apparently tabular form and be- comes a steep-sided trangressive body. The western three-fourths of the pluton is composed predominantly of hornblende diorite and gabbro with local areas of quartz diorite. The eastern one-fourth of the pluton is quartz diorite. A small body of alaskite of quartz monzonite composition intrudes the quartz diorite on Craggy Mountain (fig. 2). A small roof pendant of serpentinite occurs in the western end of the pluton west of Dona Creek. The boundary between the predominantly dioritic western three-fourths of the pluton and the eastern quartz diorite cannot be determined, as exposures are poor; it may be either a gradational or an intrusive contact.

The Ashland pluton crops out mainly in Oregon. It is not well known in California and has been studied mainly in reconnaissance in Oregon (Wells, 1956). It is a steep-sided transgressive body that appears to be composed mainly of quartz diorite and granodiorite. In northeastern Condrey Mountain quadrangle, it intrudes hornblende gabbro and has small roof pendants of serpentinite and hornblende pyroxenite.

Gabbro and diorite in the Condrey Mountain quadrangle are mesocratic (C.I. 40-60) granitic rocks that contain plagioclase. The plagioclase is commonly so saussuritized that its composition is uncertain; therefore classification of the rock as gabbro or as diorite is doubtful. The tendency is to classify the darker rocks as gabbro.

The principal mafic mineral is green hornblende that may contain traces of relict clinopyroxene. Minor amounts of chlorite partly replace the hornblende, and some epidote-clinozoisite is generally present. Minor accessories include sphene, apatite, and an opaque oxide, probably ilmenite-magnetite. Quartz is not generally a constituent but it may be present in minor amounts, as much as 5-6 percent. Analyses of three samples of gabbro, diorite, and quartz-bearing gabbro from the Vesa Bluffs pluton (Nos. 20-62, 99-64, 100-64) are given in table 10 .

The quartz diorite is leucocratic to mesocratic (C.I. 11-35) granite rock. In contrast to the gabbro and diorite, plagioclase is generally only slightly altered and shows normal compositional zoning from as calcic as labradorite in the central parts of crystals to rims of sodic andesine. Small amounts of potassium feldspar are recognizable in some specimens. Quartz is an essential constituent. Green hornblende is commonly the predominant mafic mineral; biotite generally occurs in lesser amounts. Many specimens, however, contain biotite and hornblende in nearly equal amounts, and in some, biotite is the more abundant. Other minerals present in minor amounts include apatite, chlorite, and a member of the epidote-clinozoisite group. Black opaque minerals constitute less than 0.5 percent; 
TABLE 10.-Chemical and spectrographic analyses, CIPW norms, and modes of rocks from the Vesa Bluffs and Ashland plutons

[Chemical analyses: No. 116-38, conventional analysis by F. S. Grimaldi; all others, rapid analyses by P. L. D. Elmore, S. D. Botts, Gillison Chloe, Lowell Artis, and Hezekiah Smith. Semiquantitative spectrographic analyses; samples 2, 3,10 by W. B. Crandell; 4, 6, 7, 8, 9 by R. E. Mays; 11, 11 by Carolyn Pickett; 8 by Chris Heropoulos. Sample localities shown in fig. 2]

\begin{tabular}{|c|c|c|c|c|c|c|c|c|c|c|c|c|}
\hline Sample No. & $20-62$ & $99-64$ & $100-64$ & $28-60$ & $116-38$ & $118-63$ & $109-63$ & $7-67$ & $77-63$ & $89-64$ & $29-60$ & $108-63$ \\
\hline \multicolumn{13}{|c|}{ Chemical analyses (weight percent) } \\
\hline - & 46.5 & 50.9 & 53.9 & 55.7 & 57.85 & 60.0 & 61.1 & 62.3 & 63.3 & 63.5 & 64.2 & 74.6 \\
\hline $\mathrm{Al}_{2} \mathrm{O}_{3}$ & 18.0 & 18.7 & 16.2 & 16.5 & 17.57 & 17.2 & 17.2 & 16.3 & 15.8 & 16.4 & 16.9 & 14.6 \\
\hline $\mathrm{Fe}_{2} \mathrm{O}_{3}$ & 2.9 & 1.4 & 2.4 & 3.9 & 1.98 & 1.7 & 2.6 & 1.3 & 1.3 & .79 & 2.4 & .53 \\
\hline $\mathrm{FeO}$ & 8.5 & 6.3 & 5.7 & 4.6 & $\begin{array}{l}1.00 \\
5.22\end{array}$ & 4.5 & $\begin{array}{l}2.0 \\
3.4\end{array}$ & 3.2 & 3.0 & 4.1 & 2.7 & .16 \\
\hline $\mathrm{MgO}$ & 6.2 & 4.5 & 5.4 & 5.2 & $\begin{array}{l}0.22 \\
3.42\end{array}$ & 2.9 & 2.3 & 3.3 & 3.4 & 2.0 & 1.9 & .26 \\
\hline $\mathrm{CaO}$ & 10.9 & 10.5 & 10.0 & 8.7 & 7.06 & 6.8 & 7.5 & 5.4 & 6.1 & 4.6 & 6.2 & .10 \\
\hline $\mathrm{Na}{ }_{2} \mathrm{O}$ & 2.7 & 3.5 & 2.7 & 2.0 & 3.27 & $\begin{array}{l}0.0 \\
2.8\end{array}$ & 3.2 & 3.5 & $\begin{array}{l}0.1 \\
3.9\end{array}$ & 3.9 & 2.8 & 4.7 \\
\hline $\mathrm{K}_{2} \mathrm{O}$ & .50 & $\begin{array}{l}0.0 \\
1.0\end{array}$ & 1.1 & $\begin{array}{l}2.0 \\
.89\end{array}$ & 1.29 & 1.4 & 1.1 & 2.9 & 1.4 & 2.5 & 1.6 & 4.6 \\
\hline $\mathrm{H}_{2} \mathrm{O}_{-}$ & .07 & $\begin{array}{r}1.0 \\
.19\end{array}$ & $\begin{array}{r}1.1 \\
.09\end{array}$ & $\begin{array}{l}.09 \\
.13\end{array}$ & $\begin{array}{r}1.29 \\
.07\end{array}$ & $\begin{array}{r}1.4 \\
.19\end{array}$ & .10 & .05 & $\begin{array}{r}1.4 \\
.20\end{array}$ & .12 & .11 & .12 \\
\hline $\mathrm{H}_{2} \mathrm{O}_{+}$ & 2.2 & 1.6 & 1.3 & 1.7 & .31 & 1.7 & .95 & .54 & 1.0 & 1.2 & 1.0 & .65 \\
\hline $\mathrm{TiO}_{2}$ & $\begin{array}{r}2.2 \\
.94\end{array}$ & $\begin{array}{r}1.0 \\
.73\end{array}$ & $\begin{array}{r}1.0 \\
.65\end{array}$ & .62 & 1.04 & $\begin{array}{r}1.1 \\
.39\end{array}$ & .29 & .66 & $\begin{array}{r}1.0 \\
.48\end{array}$ & $\begin{array}{r}1.2 \\
.49\end{array}$ & .33 & .04 \\
\hline $\mathrm{P}_{2} \mathrm{O}_{5}$ & .36 & .18 & .15 & .30 & $\begin{array}{r}1.0 \pm \\
.36\end{array}$ & .23 & .35 & .35 & .26 & .14 & .17 & .01 \\
\hline $\mathrm{MnO}$ & .21 & .14 & .16 & .16 & .12 & .15 & .14 & .13 & .10 & .15 & .14 & .03 \\
\hline $\mathrm{CO}_{2}$ & $<.05$ & .19 & .11 & $<.05$ & .14 & $<.05$ & $<.05$ & $<.05$ & .17 & .05 & $<.05$ & $<.05$ \\
\hline Total ........... & 100 & 100 & 100 & 100 & 99.72 & 100 & 100 & 100 & 100 & 100 & 100 & 100 \\
\hline Sp. Gr. (bulk) -- & 3.02 & 2.94 & 2.92 & 2.93 & - & 2.77 & 2.78 & 2.77 & 2.75 & 2.73 & 2.79 & 2.56 \\
\hline
\end{tabular}

Semiquantitative spectrographic analyses (ppm)

\begin{tabular}{|c|c|c|c|c|c|c|c|c|c|c|c|c|}
\hline $\mathrm{B}$ & 30 & - & - & - & - & - & - & 20 & 15 & - & $<30$ & - \\
\hline $\mathrm{Ba}$ & 200 & 300 & 500 & 500 & - & 700 & 500 & 1000 & 700 & 1000 & 1000 & 100 \\
\hline $\mathbf{B e}$ & - & - & - & - & - & - & - & - & - & - & & 3 \\
\hline Co & 30 & 30 & 20 & 20 & - & 15 & 15 & 20 & 10 & 10 & 15 & - \\
\hline $\mathrm{Cr}$ & 20 & 70 & 30 & 30 & - & 7 & 17 & 70 & 30 & 20 & 20 & 2 \\
\hline $\mathrm{Cu}$ & 700 & 15 & 100 & 200 & - & 70 & 70 & 50 & 50 & 10 & 30 & 5 \\
\hline $\mathrm{Ga} \ldots \ldots$ & 15 & 15 & 10 & 15 & - & 15 & 15 & 15 & 15 & 10 & 15 & 15 \\
\hline La $\ldots \ldots$ & - & - & - & - & - & - & 一 & 50 & - & 一 & - & - \\
\hline $\mathrm{Nb}$ & - & - & - & - & - & - & - & 10 & - & - & - & - \\
\hline $\mathrm{Ni}$ & 30 & 50 & 50 & 15 & - & 5 & 5 & 50 & 10 & $<30$ & - & - \\
\hline $\mathrm{Pb}$ & 20 & - & - & - & - & - & - & 20 & 20 & - & 30 & - \\
\hline Sc $\ldots \ldots$ & 30 & 30 & 30 & 20 & - & 15 & 15 & 20 & 15 & 10 & 15 & - \\
\hline $\mathrm{Sr} \ldots \ldots \ldots$ & 1000 & 700 & 500 & 1000 & - & 1500 & 1000 & 1000 & 1500 & 500 & 1500 & 70 \\
\hline $\mathrm{V}$ & 300 & 200 & 200 & 200 & - & 150 & 150 & 100 & 100 & 100 & 150 & - \\
\hline Y & 30 & 7 & 10 & 15 & - & 15 & 15 & 20 & 20 & 7 & 20 & - \\
\hline $\mathrm{Yb} \mathrm{b}_{-} \ldots$ & 3 & - & 1 & 2 & - & 2 & 2 & 2 & 2 & - & 2 & \\
\hline $\mathrm{Zr}$ & 30 & 30 & 10 & $7 \overline{0}$ & - & $5 \overline{0}$ & $7 \overline{0}$ & $1 \overline{5}$ & 100 & 70 & 100 & 100 \\
\hline
\end{tabular}

CIPW norms (percent)

\begin{tabular}{|c|c|c|c|c|c|c|c|c|c|c|c|c|}
\hline $\mathrm{q}_{-\ldots \ldots} \ldots$ & - & - & 5.8 & 14.7 & 12.63 & 17.6 & 19.2 & 14.5 & 17.9 & 16.4 & 25.1 & 29.1 \\
\hline$c_{-} \ldots \ldots$ & - & - & - & - & - & - & - & - & - & - & - & 1.7 \\
\hline or & 3.0 & 5.9 & 6.5 & 5.2 & 7.62 & 8.3 & 6.5 & 17.2 & 8.3 & 14.8 & 9.5 & 27.2 \\
\hline$a b$ & 22.8 & 29.6 & 22.8 & 16.9 & 27.67 & 23.7 & 27.1 & 29.6 & 33.0 & 33.0 & 23.7 & 39.8 \\
\hline an & 35.5 & 32.4 & 28.8 & 33.4 & 29.45 & 30.2 & 29.3 & 20.2 & 21.5 & 19.9 & 28.8 & .4 \\
\hline di-wo & 6.8 & 7.2 & 8.0 & 3.2 & .98 & .8 & 2.3 & 1.8 & 2.5 & .7 & .35 & - \\
\hline di-en & 3.7 & 3.8 & 4.8 & 2.2 & .53 & .4 & 1.3 & 1.1 & 1.6 & .3 & .21 & - \\
\hline di-fs & 2.9 & 3.2 & 2.8 & .8 & .41 & .4 & .9 & .55 & .73 & .4 & .12 & - \\
\hline hy-en & 1.9 & 3.3 & 8.6 & 10.7 & 7.98 & 6.7 & 4.4 & 7.1 & 6.8 & 4.7 & 4.5 & .6 \\
\hline hy-fs $\ldots \ldots$ & 1.5 & 2.8 & 5.0 & 3.7 & 6.05 & 6.1 & 3.0 & 3.4 & 3.1 & 5.9 & 2.6 & - \\
\hline fo & 6.9 & 2.9 & - & - & - & - & - & - & - & - & - & - \\
\hline fa $\ldots \ldots$ & 5.9 & 2.7 & - & - & - & - & - & - & - & - & - & - \\
\hline $\mathrm{mt} \ldots \ldots \ldots$ & 4.2 & 2.0 & 3.5 & 5.6 & 2.87 & 2.5 & 3.8 & 1.9 & 1.9 & 1.1 & 3.5 & .5 \\
\hline $\mathrm{hm}$ & - & - & - & - & - & - & - & - & - & - & - & .2 \\
\hline il & 1.8 & 1.4 & 1.2 & 1.2 & 1.98 & .74 & .55 & 1.2 & .91 & .93 & .63 & .08 \\
\hline ap & .85 & .43 & .36 & .71 & .85 & .54 & .83 & .83 & .62 & .33 & .40 & .02 \\
\hline cc & - & .43 & .25 & - & .32 & - & - & - & .39 & .11 & - & - \\
\hline
\end{tabular}

sphene is sparse or absent, and typically zircon is present in traces. Analyses of representative samples of quartz diorite from the Vesa Bluffs and Ashland plutons are given in table 10.

Granodiorite is not so abundant as quartz diorite and in most places has not been mapped separately. In general, it is lighter than quartz diorite; its color index is less than 10 although it may have as much as 25 percent mafic constituents. Potassium feldspar, including both orthoclase and microcline, amounts to about 13-20 percent in the specimens studied. Hornblende, biotite, and to a minor extent muscovite, are the mafic minerals. Biotite may be predominant; in some specimens, it is the only mafic mineral except for minor 
TABLE 10.-Chemical and spectrographic analyses, CIPW norms, and modes of rocks from the Vesa Bluffs and Ashland plutons - Continued

\begin{tabular}{|c|c|c|c|c|c|c|c|c|c|c|c|c|}
\hline Sample No. & $20-62$ & $99-64$ & $100-64$ & $28-60$ & $116-38$ & $118-63$ & $109-63$ & $7-67$ & $77-63$ & $89-64$ & $29-60$ & $108-63$ \\
\hline \multicolumn{13}{|c|}{ Modal analyses (volume percent) } \\
\hline Quartz $\ldots \ldots \ldots$ & 0.7 & 1 & 6.5 & 12 & 14 & 16 & 17 & 13 & 18 & 22 & 24 & 33 \\
\hline K-feldspar & - & - & - & - & - & 1.3 & - & 16 & $\operatorname{tr}$ & 5 & 1 & 24 \\
\hline Plagioclase _. & $44^{1}$ & $59^{1}$ & 43 & 32 & 56 & 56 & 57 & 48 & 54 & 52 & 51 & 40 \\
\hline Hornblende & 46 & 37 & 43 & 25 & 26 & 14 & 9 & 13 & 14 & 13 & 4 & - \\
\hline Biotite & - & - & - & - & 4 & 8 & 11 & 9 & 10 & 7 & 13 & - \\
\hline Muscovite (sericite) - - & - & - & - & - & - & - & 1.3 & - & - & - & .5 & 2.4 \\
\hline Sphene & .6 & .5 & .2 & - & - & 一 & - & .3 & .1 & - & 一 & - \\
\hline Apatite & .5 & .5 & - & .3 & .5 & $\operatorname{tr}$ & .3 & .3 & $\operatorname{tr}$ & $\operatorname{tr}$ & .2 & - \\
\hline Zircon & 一 & 一 & - & - & $\operatorname{tr}$ & - & - & $\operatorname{tr}$ & $\operatorname{tr}$ & $\operatorname{tr}$ & - & - \\
\hline Opaques ............ & 6 & .1 & - & .3 & .1 & $\operatorname{tr}$ & .8 & $\operatorname{tr}$ & $\operatorname{tr}$ & .1 & .5 & 一 \\
\hline Chlorite _- & 3.2 & 2.4 & .3 & 10 & - & 3 & - & .1 & .9 & .3 & - & - \\
\hline Epidote-clinozoisite -- & $4 . \overline{2}$ & .8 & 6.5 & 21 & - & 2.3 & - & - & 1 & .6 & - & - \\
\hline
\end{tabular}

'Plagioclase completely saussuritized.

NOTE. - 20-62 Hornblende gabbro, Grouse Greek, center, west edge sec. 31, T.46 N., R.8 W., Condrey Mtn. quadrangle. 99-64 Hornblende diorite, Barkhouse Creek, eastern part sec. 26, T.46 N., R.9 W., Condrey Mtn. quadrangle. 100-64 Hornblende quartz-bearing gabbro, Barkhouse Creek, SE1/4, sec. 6, T.46 N., R.8 W., Condrey Mtn. quadrangle. 28-60 Altered hornblende quartz diorite, Rider Gulch, eastern part sec. 34, T.46 N., R.8 W., Condrey Mtn. quandrangle.

116-38 Biotite hornblende quartz diorite, West Branch Long John Creek, Talent quadrangle, Oregon (not shown in fig. 2).

118-63 Biotite hornblende quartz diorite, Dona Creek, S. part sec. 20, T.46 N., R.9 W., Condrey Mtn. quadrangle. 109-63 Hornblende biotite quartz diorite, The Craggies, NE1/4, sec. 27, T.46 N., R.8 W., Condrey Mtn. quadrangle.

7-67 Biotite hornblende granodiorite, center, SE1/4, sec. 18, T.39 S., R.1 E., Ashland quad., Oregon (not shown in fig. 2).

77-63 Biotite hornblende quartz diorite, Hungry Creek, NE $1 / 4$, sec. 33, T.48 N., R.8 W., Condrey Mtn. quadrangle.

89-64 Biotite hornblende quartz diorite, Line between secs. 5 and 8, T.45 N., R.9 W., Condrey Mtn. quadrangle.

29-60 Hornblende biotite quartz diorite, Vesa Bluffs, W. part sec. 22, T.46 N., R.8 W., Condrey Mtn. quadrangle.

108-63 Alaskite of quartz monzonite composition, E. part sec. 27, T.46 N., R.8 W., Condrey Mtn. quadrangle.

secondary chlorite. The rock contains apatite and opaque metallic minerals in minor amounts and traces of zircon. Analysis of a sample of granodiorite from the Ashland pluton is given in table 10, No. 7-67.

Alaskite of quartz monzonite composition on Craggy Mountain in the eastern part of Vesa Bluffs pluton has no hornblende or biotite. It is composed principally of plagioclase, quartz, and potassium feldspar with minor amounts of white mica. An analysis of a sample of the rock from Craggy Mountalin is given in table 10, No. $108-63$.

\section{AGE}

Potassium-argon ages have been determined for the Vesa Bluffs and Ashland plutons. For the Ashland pluton, concordant ages of 146 and $147 \pm 4$ m.y. were obtained on hornblende and biotite, respectively, from a sample in Condrey Mountain quadrangle (Lanphere and others, 1968); two determinations on hornblende from a sample of quartz diorite collected near Ashland, Ore., yielded ages of $160 \pm 5$ m.y. and $166 \pm 5$ m.y., whereas biotite from the same sample gave an age of $144 \pm 4$ m.y. (Hotz, 1971, fig. 10). Discordant ages of $160 \pm 5$ m.y. and $146 \pm 4$ m.y. were obtained on hornblende and biotite, respectively, from a sample of quartz diorite from the Vesa Bluffs pluton (Lanphere and others, 1968). In all the mineral pairs except one from the Ashland pluton, hornblende,with a spread of 13 m.y., yields a somewhat older age than biotite; biotite is younger and has a range of only $3 \mathrm{~m}$.y. In view of the narrower range of the biotite ages and the concordance with hornblende in one sample, the biotite ages of 144-147 m.y., which correspond to Late Jurassic time, are assumed to be the approximate age of crystallization of the pluton.

\section{STRUCTURAL AND METAMORPHIC RELATIONS}

The Condrey Mountain Schist is structurally beneath the higher grade amphibolite and associated metasedimentary rocks. The contact is undoubtedly a thrust fault, probably modified in many places by high-angle faulting. In some places a thin gently dipping tabular body of serpentinite occurs at the contact, and at a few places far out in the central part of the quartz-mica schist terrane, a few small thin sheets of serpentinite overlie and are infolded with the schist (fig. 1); these sheets are probably remnants of more continuous serpentinite that may have occurred between the schist and the overriding amphibolite terrane.

The structural and metamorphic history must explain the absence of ultramafic and plutonic rocks in the window of Condrey Mountain Schist and the concentration of these rocks in the amphibolite facies zone. The absence of serpentinite, except for the few remnants infolded with the schist, is strong evidence that the thrusting that juxtaposed these two terranes was later than the episode of ultramafic rock emplacement. These serpentinite remnants, possibly at or near the 
contact with the underlying amphibolite, may have been emplaced cold at the time of thrusting.

In general, the change from rocks of the amphibolite facies to overlying metavolcanic and metasedimentary rocks of the greenschist facies to the east and west is less well defined. Westward, in the Seiad Valley quadrangle and the southern part of the Ruch quadrangle, Oregon (fig. 1), metasedimentary rocks belonging to the amphibolite facies are overlain by metavolcanic rocks, probably along a fault (N. J Page, written commun., 1976). In the southern Condrey Mountain quadrangle, faults and serpentinite bodies separate the two terranes, and the roughly tabular southward-dipping Vesa Bluffs pluton occurs between amphibolite facies rocks and greenschist facies metavolcanic and metasedimentary rocks. No well-defined contact between nonfoliated metavolcanic rocks of the amphibolite facies and those of the greenschist facies has been recognized east of the large eastern ultramafic body in eastern Condrey Mountain quadrangle. The nonfoliated amphibolite that occurs east of the serpentinite is succeeded upward, apparently conformably, by fine-grained greenschist facies metasedimentary and metavolcanic rocks of the western Paleozoic and Triassic belt. The biotite isograd in metasedimentary rock is approximately $3 \mathrm{~km}$ east of the main serpentinite body. There appears to be a gradual decrease in the intensity of metamorphism stratigraphically upward east of the easternmost ultramafic bodies.

The significant break in the Condrey Mountain quadrangle between the terranes of foliated and nonfoliated amphibolite is north of the Vesa Bluffs pluton, where a gently dipping contact interpreted as a fault separates them. In Little Humbug Creek, the fault is partly occupied by gently dipping tabular serpentinite bodies. The western part of the fault is intersected by the Vesa Bluffs pluton. The northern continuation of the fault may be the nearly east-west steeply dipping fault south of and parallel to the Klamath River east of the mouth of Beaver Creek. North of the Klamath River, the identity of the break becomes lost beyond the place where the east-west-trending fault is intersected by the large eastern serpentinite body. This break may have been the original discontinuity between foliated amphibolite and the metavolcanic-metasedimentary rock terrane.

The association of ultramafic rocks and amphibolite is fairly common worldwide. Some geologists have ascribed the amphibolite to contact metamorphism of basaltic rocks by the ultramafic intrusions (Challis, 1965; Green, 1964). Williams (Williams and Smyth, 1973) regards amphibolite associated with ultramafic rocks in Newfoundland as contact dynamothermal aureoles related to obduction and transport of ophiolite slices. In the Condrey Mountain quadrangle, the occurrence of numerous discontinuous metamorphosed serpentinite bodies interlayered conformably with the foliated amphibolite is indicative of simultaneous deformation and metamorphism of disrupted ophiolitic rocks, possibly a melange. The potassium-argon age of the amphibolite is in general agreement with the age of the plutonic rocks; either the metamorphism and plutonism were simultaneous events or the metamorphism was earlier than the plutonism and the potassium-argon ages were modified by heat of the intrusions. As both samples of dated amphibolite were taken about $5 \mathrm{~km}$ from the Vesa Bluffs and Ashland plutons, it seems unlikely that they would be affected by later heating.

Clearly for the Condrey Mountain Schist and the amphibolite facies to be brought together, these rocks of contrasting lithologies have been juxtaposed by large-scale horizontal displacements. The ages of metamorphism of the amphibolite and schist are approximately the same, suggesting that at about the time in the Late Jurassic the metamorphism of the amphibolite took place, sedimentary and minor amounts of volcanic rock, probably of the Galice Formation, were overthrust by the amphibolite or dragged beneath it. Penetrative deformation and heating caused by deeper burial, possibly together with the higher temperature of the overthrust sheet, resulted in metamorphism of rocks below the thrust sheet to form the Condrey Mountain Schist.

An earlier tectonic-metamorphic episode under lowtemperature high-pressure conditions is represented by phyllite of the Stuart Fork Formation, which contains blueschist of Triassic age (220 m.y.) in the Yreka-Fort Jones area (Hotz and others, 1977). Here the Stuart Fork occurs adjacent to serpentinite of Ordovician (?) age, which is between lower Paleozoic rocks of the eastern Klamath belt and metavolcanic and metasedimentary rocks of the western Paleozoic and Triassic belt. Thrusting of the Stuart Fork over these rocks probably took place during the Triassic metamorphism and may have continued or may have been renewed in the Jurassic.

\section{REFERENCES CITED}

Barrows, A. G., 1969, Geology of the Hamburg-McGuffy Creek area, Siskiyou County, California, and petrology of the Tom Martin ultramafic complex: California University at Los Angeles, Ph.D. thesis, $301 \mathrm{p}$.

Cann. J. R., 1971, Major element variations in ocean floor basalts: Royal Society London Philosophical Transactions, v. A268, p. 495-505.

Challis, G. A., 1965, High temperature contact metamorphism at the Red Hills ultramafic intrusion-Wairu Valley-New Zealand: Journal Petrology, v. 6, no. 3, p. 395-419. 
Chidester, A. H., 1962, Petrology and geochemistry of selected talcbearing ultramafic rocks and adjacent country rocks in northcentral Vermont: U.S. Geological Survey Professional Paper 345, $207 \mathrm{p}$.

Davis, G. A., 1968, Westward thrust faulting in the south-central Klamath Mountains, California: Geological Society America Bulletin, v. 79, no. 7, p. 911-934.

Davis, G. A., and Lipman, P. W., 1962, Revised structural sequence of pre-Cretaceous metamorphic rocks in the southern Klamath Mountains, California: Geological Society America Bulletin, v. 73 , p. $1547-1552$.

Davis, G. A., Holdaway, M. J., Lipman, P. W., and Romey, W. D., 1965, Structure, metamorphism, and plutonism in the south-central Klamath Mountains, California: Geological Society America Bulletin, v. 76 , no. 8, p. 933-965.

Elliott, M. A., 1971, Stratigraphy and petrology of the Late Cretaceous rocks near Hilt and Hornbrook, Siskiyou County, California, and Jackson County, Oregon: Oregon State University, Corvallis, Ph.D. thesis, $171 \mathrm{p}$.

Engelhardt, C. L., 1966, The Paleozoic-Triassic contact in the Klamath Mountains, Jackson County, southwest Oregon: Oregon University, Eugene, M. A. thesis, 98 p.

Fyfe, W. S., Turner, F. J., and Verhoogen, John, 1958, Metamorphic reactions and metamorphic facies: Geological Society America Memoir 73, 259 p.

Green, D. H., 1964, The metamorphic aureole of the peridotite at the Lizard, Cornwall: Journal Geology, v. 72, no. 5, p. 543-563.

Hamilton, Warren, 1963, Metamorphism in the Riggins region, western Idaho: U.S. Geological Survey Professional Paper 436, 95 p.

Heinrich, M. A., 1966, Geology of the Applegate Group, Kinney Mountain area, southwest Jackson County, Oregon: Oregon University, Eugene, M.A. thesis, 107 p.

Holdaway, M. J., 1965, Basic regional metamorphic rocks in part of the Klamath Mountains, northern California: American Mineralogist, v. 50, p. 953-977.

Hotz, P. E., 1967, Geologic map of the Condrey Mountain quadrangle and parts of the Seiad Valley and Hornbrook quadrangles California: U.S. Geological Survey Geological Quadrangle Map GO-618, scale 1:62,500.

1971, Plutonic rocks of the Klamath Mountains, California and Oregon: U.S. Geological Survey Professional Paper 684-B, $20 \mathrm{p}$.

_-1973, Blueschist metamorphism in the Yreka-Fort Jones area, Klamath Mountains, California: U.S. Geological Survey Journal Research, v. 1, no. 1, p. 53-61.

Hotz, P. E., Lanphere, M. A., and Swanson, D. A., 1977, Triassic blueschist from northern California and north-central Oregon: Geology, v. 5, No. 11 p. 659-663.

Irwin, W. P., 1960, Geological reconnaissance of the northern Coast Ranges and Klamath Mountains, California, with a summary of the mineral resources: California Division Mines Bulletin 179, $80 \mathrm{p}$.

1966, Geology of the Klamath Mountains province, in Bailey, E. H., ed., Geology of northern California: California Divison Mines and Geology Bulletin 190, p. 16-38.

1972, Terranes of the Western Paleozoic and Triassic belt in the southern Klamath Mountains, California: U.S. Geological Survey Professional Paper 800-C, p. C103-C111.

1977, Ophiolitic terranes of California, Oregon and Nevada, in
North American ophiolites: Oregon Department Geology and Mineral Industries Bulletin 95, p. 75-92.

Irwin, W. P., Jones, D. L., and Pessagno, E. A., Jr., 1977, Significance of Mesozoic radiolarians from the pre-Nevada rocks of the southern Klamath Mountains, California: Geology, v. 5, no. 9, p. 557-562.

Kay, R. W., Hubbard, N. J., and Gast, P. W., 1970, Chemical characteristics and origin of oceanic ridge volcanic rocks: Journal Geophysical Research, v. 75, p. 1585-1613.

Kays, M. A., 1968, Zones of alpine tectonism and metamorphism, Klamath Mountains, southwestern Oregon: Journal Geology, v. 76 , p. $17-36$.

1970, Mesozoic metamorphism, May Creek Schist belt, Klamath Mountains, Oregon: Geological Society America Bulletin, v. 81 , p. $2743-2758$.

Klein, C. W., 1976, Thrust faulting in the Klamath Mountains, northwest California-evidence at Happy Camp for the origin of the schists of Condrey Mountain: Geological Society America Abstracts with Programs, v. 8, no. 3, p. 388 .

Lanphere, M. A., Irwin, W. P., and Hotz, P. E., 1968, Isotopic age of the Nevadan orogeny and older plutonic and metamorphic events in the Klamath Mountains, California: Geological Society America Bulletin, v. 79, p. 1027-1052.

Medaris, L. G., 1966, Geology of the Seiad Valley area, Siskiyou County, California, and petrology of the Seiad ultramafic complex: California University at Los Angeles, Ph.D. thesis, 359 p.

Page, N. J., 1966, Mineralogy and chemistry of the serpentine group minerals and the serpentinization process: California University, Berkeley, Ph.D. thesis, $351 \mathrm{p}$.

Pratt, W. P., 1964, Geology of the Marble Mountain area, Siskiyou County, California: Stanford University, Stanford, Calif., Ph.D. thesis, $116 \mathrm{p}$.

Rynearson, G. A., and Smith, C. T., 1940, Chromite deposits in the Seiad quadrangle, Siskiyou County, California: U.S. Geological Survey Bulletin 922, p. 281-306.

Snoke, A. W., 1977, A thrust plate of ophiolitic rocks in the Preston Peak area, Klamath Mountains, California: Geological Society America Bulletin, v. 88, p. 1641-1659.

Suppe, John, and Armstrong, R. L., 1972, Potassium-argon dating of Franciscan metamorphic rocks; American Journal Science, v. 272 , no. 3 , p. $217-233$.

Trommsdorff, Volkman, and Evans, B. W., 1974, Alpine metamorphism of peridotitic rocks: Schweizerische Mineralogische und Petrographische Mitteilungen v. 54, no. 2-3, p. 333-354.

Wells, F. G., 1956, Geology of the Medford quadrangle OregonCalifornia: U.S. Geol. Survey Quadrangle Map GO-89, scale 1:96,000.

Wells, F. G., and others, 1940, Preliminary geologic map of the Grants Pass quadrangle, Oregon: Oregon Department Geology and Mineral Industries, scale 1:96,000.

Wells, F. G., Hotz, P. E., and Cater, F. W., 1949, Preliminary description of the geology of the Kerby quadrangle, Oregon: Oregon Department Geology and Mineral Industries Bulletin 40, $23 \mathrm{p}$.

Wells, F. G., and Peck, D. L., 1961, Geologic map of Oregon west of the 121st meridian: U.S. Geological Survey Miscellaneous Geological Investigation Map I-325.

Williams, Harold, and Smyth, W. R., 1973, Metamorphic aureoles beneath ophiolite suites and alpine peridotites: tectonic implications with west Newfoundland examples: American Journal Science, v. 273, p. 594-621. 
